\title{
Intravesical device-assisted therapies for non-muscle invasive bladder cancer
}

Wei Shen $\operatorname{Tan}^{1,2}$ and John D. Kelly ${ }^{1,2}$

${ }^{1}$ Division of Surgery and Interventional Science, University College London, London, UK

${ }^{2}$ Department of Urology, University College London Hospital, London, UK

Email: wei.tan@ucl.ac.uk

Abstract | Non-muscle-invasive bladder cancer (NMIBC), the most prevalent type of bladder cancer accounts for approximately $75 \%$ of bladder cancer diagnoses. This disease has a $50 \%$ risk of recurrence and $20 \%$ risk of progression within 5 years , despite the use of intravesical adjuvant treatments (such as BCG or mitomycin C (MMC)) that are recommended by clinical guidelines. Intravesical device-assisted therapies, such as radiofrequency-induced thermochemotherapeutic effect (RITE), conductive hyperthermic chemotherapy, and electromotive drug administration (EMDA), have shown promising efficacy. These deviceassisted treatments are an attractive alternative to BCG, as issues with supply has been a problem in some countries. RITE might be an effective treatment option in patients who have experienced BCG failure and are not candidates for radical cystectomy. Data from trials using EMDA suggest it is effective in high risk disease but require further validation and results of randomised trials are eagerly awaited for conductive hyperthermic chemotherapy. Considerable heterogeneity in patient cohorts, treatment sessions, use of maintenance regimens, and single-arm study design makes it difficult to draw solid conclusions, although randomized controlled trials have been reported for RITE and EMDA. 


\section{[H1] Introduction}

Bladder cancer is the ninth most common cancer worldwide and is the thirteenth most common cause of cancer-associated mortality. ${ }^{1}$ Non-muscle-invasive bladder cancer (NMIBC) is the most frequently diagnosed type of bladder cancer; approximately $75 \%$ of bladder cancers are NMIBC. The main stay of NMIBC management is by transurethral resection of bladder tumour (TURBT). NMIBC is stratified into low-risk, intermediate-risk, and high-risk categories using clinical and pathological factors. In the UK, intermediate-risk NMIBC is treated with adjuvant chemotherapy while high-risk NMIBC is treated with adjuvant immunotherapy. ${ }^{2}$ Neoadjuvant chemoablation has been described but is not standard of care within NMIBC guidelines due to limited level one evidence. , $^{3,4}$

A single post-TURBT instillation of chemotherapy as adjuvant therapy within 24 hours, but ideally within 6 hours, reduces the relative risk of recurrence by $35 \%$ (HR: $0.65,95 \% \mathrm{Cl} 0.58-$ 0.74 ) in an individual patient data meta-analysis of low, intermediate and high-risk NMIBC. ${ }^{5} \mathrm{~A}$ course of intravesical chemotherapy is recommended for intermediate-risk NMIBC and reduces the relative risk of recurrence by $44 \%(\mathrm{HR}: 0.56,95 \% \mathrm{Cl}: 0.48-0.65) .{ }^{6}$ Mitomycin C (MMC) is the most commonly used intravesical chemotherapy. ${ }^{7}$. MMC is a cytotoxic antibiotic that induces cell death by alkylation and cross linking of DNA. ${ }^{8}$ Its molecular weight of 334 $\mathrm{kDa}$ minimizes the risk of systemic absorption and toxic effects such as myelosuppression and pulmonary toxicity. ${ }^{8}$ Adverse events following intravesical delivery of MMC are predominantly local irritative voiding symptoms, which are reported in up to $39 \%$ of patients. ${ }^{9}$ Evidence exists for alternative agents including gemcitabine, epirubicin, and Adriamycin, which have not been as commonly adopted as MMC due to less compelling evidence although recent studies have suggested that gemcitabine is efficacious and may be an alternative to MMC. ${ }^{10-12}$

Intravesical BCG is recommended for high-risk NMIBC as a 6 once weekly induction course followed by a maintenance regime of 3 once weekly instillations at 3 and 6 months followed by every subsequent 6 months for up to 3 years. ${ }^{13}$ Maintenance BCG has been shown to increase absolute survival advantage by $5 \%$ at 5 years compared with induction BCG alone, supporting the use of maintenance treatment. ${ }^{13}$ However, up to $65 \%$ of patients treated with BCG report local toxicities and $12 \%$ of patients do not complete maintenance therapy. ${ }^{14}$ Since 2012 , availability of BCG has become an issue in some countries and the production of the Connaught strain is expected to cease in 2019 further limiting availability. ${ }^{15}$ Thus, the development of alternative intravesical treatments for bladder cancer is imperative.

Despite use of adjuvant therapies, up to $52 \%$ of patients with high-risk NMIBC will have disease recurrence and $20 \%$ will progress to muscle-invasive bladder cancer (MIBC) within 5 years. ${ }^{16}$ Radical cystectomy is the standard-of-care treatment after BCG failure, although rechallenging with further BCG remains an option according to National Comprehensive Cancer Network guidelines.. ${ }^{2,17}$

Developments for the treatment of NMIBC have focused on optimizing the delivery of established therapies or potentiating the effects of chemotherapy using intravesical deviceassisted technology to deliver hyperthermia to the bladder wall or circulating chemotherapy and ionisation of chemotherapy to improve drug tissue penetration. The three most used 
devices are radiofrequency-induced thermochemotherapeutic effect (RITE), conductive hyperthermic chemotherapy, and electromotive drug administration (EMDA) chemotherapy. Depot delivery devices, where slow releasing formulation of chemotherapy over an extended period of time, have been reported and are in early phase development. ${ }^{18,19}$ In this Review, we describe the evidence for intravesical device-assisted technologies and summarize efficacy, safety, and tolerability outcomes. We also highlight other potential devices that are promising for the treatment of NMIBC.

\section{[H1] Hyperthermia as a treatment}

The use of hyperthermia to treat bladder cancer is based on the concept that heat can potentiate the effect of chemotherapy. ${ }^{20}$ In vitro studies demonstrated that hyperthermia results in the denaturation of cytoplasmic structures and enzymatic proteins, inducing cell death by apoptosis and necrosis. ${ }^{21-23}$ Temperature elevation enhances cell membrane permeability resulting in increased drug absorption. ${ }^{24,25}$ Hyperthermia also causes the release of heat shock proteins (HSP), in particular HSP70, during cellular necrosis, which stimulates an adaptive T-cell response to induce the innate and adaptive immune system, despite promoting thermotolerance ${ }^{26,27}$. Furthermore, at $42^{\circ} \mathrm{C}$ exponential cell death seems to occur; above this temperature the benefit of hyperthermia might be minimal, but toxic effects might become apparent. ${ }^{21}$ Cancer cells are more susceptible to hyperthermia than nonmalignant cells and, in clinical practice, hyperthermia is usually delivered at $42^{\circ} \mathrm{C}$, although $45^{\circ} \mathrm{C}$ has been described. ${ }^{28}$ Data from cell lines demonstrates synergism, whereby the effect of hyperthermia plus chemotherapy is greater than the combined additive effect. ${ }^{29,30}$ Hyperthermia might also chemosensitize tumours to alkylating agents such as MMC via HSP mediated pathways. ${ }^{26}$

In the clinical setting, hyperthermia has been used in combination with chemotherapy for the treatment of NMIBC. ${ }^{31,32} 33$ Hyperthermia can be either delivered by intravesical radiofrequency-induced hyperthermia or conductive heat via energy transfer from heated circulating fluid. ${ }^{31,32} 33$ Deep regional hyperthermia by radiofrequency is feasible and has been reported but is not in widespread use in clinical practice, although it might be effective in MIBC as well as NMIBC. ${ }^{34}$

\section{[H1] RITE}

Radiofrequency-induced hyperthermia is an established therapy for a number of cancers including hepatocellular carcinoma, ${ }^{35}$ Barrett's oesophagus, ${ }^{36}$ breast cancer ${ }^{37}$, and lung cancer. ${ }^{38}$ Radiofrequency is delivered to tissues with high perfusion and poor electrical and thermal conductivity at a frequency of $350-500 \mathrm{kHz}$ for the treatment of localized solid organ tumours. $^{39,40}$ In contrast, RITE is delivered to the entire bladder at a frequency of $915 \mathrm{MHz}$ using microwave which does not require conductive delivery of energy and penetrate lowconductive tissues. ${ }^{40}$ This is ideal for the delivery of heart energy directly to the tissue to enable an efficient effect on the full bladder wall thickness. Pharmacokinetic analysis showed that RITE with $40 \mathrm{mg} \mathrm{MMC} \mathrm{over} 60$ minutes resulted in >10-fold higher MMC concentration in bladder cancer tissue than passive intravesical MMC (median $665 \mathrm{ng} / \mathrm{g}$ versus 
$64 \mathrm{ng} / \mathrm{g}, P=0.018) .{ }^{41}$ Plasma concentrations of MMC in patients treated using RITE plus MMC increased rapidly within 15 minutes and continued to increase and peak between 45 to 60 minutes ${ }^{42}$ In comparison, there was a dose response increase in patients treated with passive mitomycin and MMC plasma concentration peaks at 15 minutes and remained stable over 60 minutes. ${ }^{42}$ In addition, a report by Ware et al. ${ }^{43}$ suggest that radiofrequency promotes the formation of tunnelling nanotubes within cancer cells, which might increase drug diffusion and increase efficiency. ${ }^{43}$

RITE therapy for bladder cancer is the most established device-assisted therapy and the Synergo system was first reported in $1995 .{ }^{44}$ The Synergo system comprises a microwave radiofrequency source generating energy at $915 \mathrm{MHz}$ from an antenna located at the tip of a Foley catheter (Fig. 1). The specialized triple lumen 18/20 Fr Foley catheter consists of the inflow and outflow lumen, the energy source antenna, and intravesical thermocouples at the catheter tip and proximal urethra that are used to monitor bladder wall temperature. ${ }^{44}$ The radiofrequency antenna delivers hyperthermia at $42 \pm 2^{\circ} \mathrm{C}$ to the bladder wall by direct radiation, while the inflow and outflow channel recirculate chemotherapy at room temperature $\left(22^{\circ} \mathrm{C}\right)$ within a closed system.

Treatment comprises two 30-minute sessions; between each session the bladder is emptied and a new solution of MMC is instilled, reducing the dilutional effect of diuresis. ${ }^{45} \mathrm{An}$ adjuvant treatment protocol consists of two 30-minute sessions of $20 \mathrm{mg} \mathrm{MMC} \mathrm{instillations} \mathrm{dissolved} \mathrm{in}$ $40 \mathrm{ml}$ of saline or water. An ablative protocol of two 30 -minute sessions of $40 \mathrm{mg} \mathrm{MMC}$ in 40 $\mathrm{ml}$ of saline or water is recommended in the manufacturer's protocol. ${ }^{46}$ The requirement for intravesical administration of MMC midway of treatment session with RITE requires additional nursing input. An induction protocol of 6-8 once weekly treatments is administered followed by a maintenance protocol of one treatment every 6 weeks for the first year and one treatment every 8 weeks for the second year. ${ }^{47}$ An alternative protocol of six once weekly induction protocol with a maintenance protocol of three once weekly instillations at 3, 6, and 12 months has been reported. ${ }^{31}$ No comparisons between the two protocols because they have been used in different patient cohorts.

\section{[H2] Treatment efficacy}

To date, 21 reports from 20 studies on the efficacy of RITE for NMIBC have been published (Table 1); five studies report outcomes for RITE delivered in the pre-TURBT ablative setting, ${ }^{44,48-51}$ nine studies in the adjuvant setting ${ }^{47,52-60}$ and six studies had a mixture of patients treated with adjuvant therapy or pre-TURBT ablative treatment. ${ }^{61-66}$ Only four randomized controlled trials (RCTs) investigating RITE have been conducted; three as adjuvant treatment ${ }^{47,53,56,60}$ and one in the ablative setting. ${ }^{50}$

Reported recurrence free survival (RFS) differs between studies, reflecting the heterogenous patient cohorts, follow-up duration, and different treatment regimens and presence of CIS In studies including patients with papillary-only disease, RFS ranges from $53 \%-91 \%$ with $9.6-$ 24-month follow-up duration. ${ }^{47,53,58-60,65,66}$ However, in patients who had isolated or concurrent CIS (13-68\%), RFS can range from $29 \%-88.6 \%$ at $14-38$-months follow-up duration. ${ }^{47,54,55,57,61-64} \mathrm{~A}$ substantial number of patients treated with RITE had developed 
recurrence after previous intravesical therapy and disease progression occurs in $0-38 \%$ of patients. ${ }^{47,49,52,53,55-65}$

In the pre-TURBT ablative setting, data from nine studies reporting outcomes from 211 patients suggest a complete response rate of $65.4 \% .^{44,48-51,62,63,65,66}$ Subsequent studies have used an increased dose of MMC for ablative therapy (two 30-minute cycles of $40 \mathrm{mg}$ MMC vs $20 \mathrm{mg}$ MMC), which might be beneficial for patients with widespread concurrent or isolated carcinoma in situ (CIS) ..$^{61,6263-6566}$ In one RCT of 52 patients, RITE resulted in significantly higher complete response rates than $\mathrm{MMC}$ alone $(66 \%$ versus $22 \%, P<0.01) .{ }^{50}$

Three RCTs compared RITE with either passive MMC or BCG ; two trials in the setting of firstline therapy and one in patients who had experienced BCG failure. Colombo et al.$^{60}$ conducted a RCT involving 83 patients comparing RITE plus MMC with passive MMC in intermediaterisk or high-risk disease. Patients in both arms (42 RITE vs 41 passive MMC) had complete TURBT followed by an induction schedule of 8 once weekly intravesical instillations and a maintenance schedule of four once-monthly instillations. Patients in the RITE arm received two 30-minute sessions of MMC (20 mg in $40 \mathrm{ml}$ saline) and patients in the passive MMC arm received $40 \mathrm{mg}$ of $\mathrm{MMC}$ in $40 \mathrm{ml}$ for 1 hour. At 24 months RFS was significantly improved in patients who received RITE (RITE: $82.9 \%$ versus passive MMC: $42.5 \%, P=0.002$ ) with no significant difference in disease progression between treatment arms. ${ }^{60}$ Subsequently, a longer-term follow-up of a median of 91 months suggested that the RFS superiority of RITE over passive MMC is sustained (RITE: $60 \%$ versus passive MMC: $20 \%, P<0.001$ ). ${ }^{56}$

Arends et al. ${ }^{31}$ later reported a RCT of 190 patients with intermediate-risk or high-risk NMIBC (92 RITE plus MMC vs 98 BCG). Patients in the RITE arm received a 6 once weekly induction course of two 30-minute sessions of $20 \mathrm{mg}$ of MMC in $50 \mathrm{ml}$ of water followed by a three once weekly maintenance course at 3, 6, and 12 months, whereas patients in the BCG arm received full dose OncoTICE for 120 minutes per session for six once weekly induction instillations and three once weekly maintenance instillations at months 3, 6 and 12 months. The trial closed early owing to slow recruitment. Intention-to-treat results for the whole patient cohort were not reported. At the 24-month follow-up point, a trend towards significance in RFS was observed in the RITE arm $(n=71)$ compared with the control arm $(n=76)$ for patients with papillary-only disease (RITE: $78.1 \%$ versus $64.8 \%, P=0.08$ ). The per-protocol analysis suggested that the RFS was significantly higher in the RITE arm than the BCG arm for patients with papillary disease (RITE: $81.8 \%$ versus BCG: $64.8 \%, P=0.02$ ). At 3 months, the complete response rate for patients with CIS was not significantly different between the two arms. This study was the first to compare RITE plus MMC with BCG therapy and, although the primary outcome was not met in the intention-to-treat analysis, the results suggest that RITE is an effective treatment for papillary NMIBC. These results are promising, but the outcomes for patients with CIS-only disease or concurrent CIS were not reported.

Tan et al. ${ }^{47}$ reported the results of the HYMN study, a multicentre phase III trial of 104 patients with intermediate-risk or high-risk NMIBC who developed recurrence after induction with or without maintenance BCG. Patients were randomized to RITE plus MMC or institutional standard practice. Patients in the RITE arm received 6 once weekly instillations of two 30- 
minute sessions of $20 \mathrm{mg} \mathrm{MMC}$ in $50 \mathrm{ml}$ of sterile water as part of induction treatment and three once weekly instillations at months 3, 6, 12, 18 and 24 months as part of maintenance treatment. Institutional standard practice comprised either rechallenge with BCG (59\%), passive MMC (18\%), or EMDA with MMC (23\%). At the 24-month follow-up point, no overall difference in intention-to-treat disease-free survival (DFS) was observed between the two treatment arms (HR 1.33; 95\% Cl: 0.84-2.10, $P=0.23$ ) or in 3-month complete response rate in patients with CIS (RITE plus MMC arm: $30 \%$ versus control: $47 \%, P=0.15$ ). There was a non-significant higher intention-to-treat DFS in papillary-only disease (HR 0.50; 95\% Cl: $0.22-$ 1.17, $P=0.11$ ) treated with RITE compared to control However, patients with CIS with/without papillary disease who received RITE had significantly higher disease recurrence than those who received treatment according to institutional standard practice (HR 2.06;95\% Cl: 1.173.62, $P=0.01$ ), which resulted in the premature closure of the trial. A subsequent study reported an ablative protocol for patients with CIS comprising two 30-minute sessions of 40 mg MMC. ${ }^{64}$ DFS in patients who received this protocol was $43 \%$ at a median of 22 months. ${ }^{64}$ The requirement for an increased MMC dose in ablative setting might explain results observed in the HYMN study.

The rate of disease progression in the HYMN trial was low (6\%) at a median follow-up duration of 35 months, which should be compared with the $5 \%$ risk of 90 -day mortality of radical cystectomy in these patients who have comorbidities. ${ }^{68}$ Despite limited RCT data, emerging evidence suggests that RITE plus MMC is a suitable alternative intravesical treatment option to passive MMC. Moreover, this modality could be considered for patients with high-risk papillary NMIBC as an alternative to BCG in the first-line setting. Results following RITE plus MMC treatment in patients with papillary-only disease who experienced BCG failure suggest this modality may be promising, but evidence is currently insufficient to support its use in patients with CIS. In fact, the FDA defined that a RFS of $\geq 25-30 \%$ at $18-24$ months as clinically meaningful in BCG refectory patients. ${ }^{67}$ Both treatment arms in HYMN achieved a RFS $>35 \%$ which was above the threshold for clinically meaningful effect although BCG failure patients recruited to HYMN had a better prognosis as BCG intolerant and relapsing patients were also included.

\section{[H2] Adverse events}

The reported adverse event rates following RITE suggest that it is well tolerated, with $92 \%$ of patients completing induction treatment. ${ }^{69}$ The most commonly reported adverse events during treatment are cystitis and/or storage lower urinary tract symptoms (LUTS) (32\%), suprapubic pain (30\%), and bladder spasm (20\%). ${ }^{47,52,6144,50,51,55,57-60,62,65,66}$ Storage LUTS such as incontinence (12.6\%) and nocturia (23.9\%) and haematuria (17.2\%) are the most common adverse events after treatment and $3.3 \%$ of patients had urethral stricture (Table 2). However, most adverse events are self-limiting and short lived. ${ }^{31,47}$ RITE recirculates room temperature MMC, hence, no thermal reaction to the urethra occurs which would theoretically minimise the risk of urethral strictures. ${ }^{70}$ latrogenic urethral injuries owing to catheter insertion might have contributed to the development of the urethral strictures reported. Thermal reaction on the posterior bladder wall, which is commonly observed following RITE treatment, can look suspicious for CIS owing to urothelium erythema and prompt unnecessary bladder biopsies 
although they are benign and does not cause long term damage. ${ }^{44}$ Indeed, animal studies suggest that the thermal reaction represent focal oedema, haemorrhage, and oedema of the lamina propria and serosa, which resolves completely. ${ }^{71}$

Adverse events reported in RCTs enable comparison of adverse event rates following RITE plus MMC or other standard-of-care treatment (Supplementary Table 1). RITE resulted in significantly more pain $(P<0.001)$ and bladder wall erythema $(P<0.001)$ than passive MMC, but no difference in dysuria, haematuria, urethral stenosis, or allergic reaction was observed. ${ }^{60}$ Patients who received RITE plus MMC had a significantly increased risk of bladder pain during treatment (OR: 26.3; 95\% Cl, 14.3-48.5) or between treatments (OR: 1.6; $95 \% \mathrm{Cl}, 1.2-2.3$ ), bladder spasms (OR: 15.5; 95\% Cl, 9.7-25.0), difficulty with catheterisation (OR: 16.7; 95\% $\mathrm{Cl}, 5.1-54.0$ ), urethral strictures (OR: $2.3 ; 95 \% \mathrm{Cl}, 1.3-4.1$ ), bladder wall erythema (OR: 5.8 ; $95 \% \mathrm{Cl}, 4.0-8.3$ ), and allergic reaction (OR: $2.7 ; 95 \% \mathrm{Cl}, 1.6-4.6)$ compared with BCG. However, significantly less urinary frequency (OR: $0.61 ; 95 \% \mathrm{Cl}, 0.49-0.75)$, nocturia (OR: $0.79 ; 95 \% \mathrm{Cl}, 0.63-0.98$ ), incontinence (OR: $0.22 ; 95 \% \mathrm{Cl}, 0.12-0.37$ ), haematuria (OR: 0.56; 95\% Cl, 0.42-0.74), fever (OR: 0.09; 95\% Cl, 0.04-0.10), fatigue (OR: 0.17 ; 95\% Cl, $0.11-$ 0.28 ), and arthralgia (OR: $0.09 ; 95 \% \mathrm{Cl}, 0.03-0.31$ ) were reported than for patients who received BCG. ${ }^{53}$

In summary, RITE treatment for bladder cancer has been shown to be efficacious in intermediate or high risk papillary only BCG naïve NMIBC in a randomised setting. In the BCG failure setting, subgroup analysis of papillary only patients showed better efficacy in RITE treated patients compared to control, but this was not significant suggesting that this may be a treatment option in this patient cohort with limited options. There is limited data specifically in the BCG refractory setting and in patients with isolated or concurrent CIS disease and future planned trials will hopefully address this question. A single-arm study, RITE-Europe which will recruit patients with BCG-refractory CIS with or without papillary NMIBC is being planned. Treatment will consist of RITE with two 30 -minute sessions of $40 \mathrm{mg} \mathrm{MMC}$.

\section{[H1] Conductive hyperthermic chemotherapy}

Conductive hyperthermic chemotherapy is an alternative technology for delivering localized hyperthermia. The chemotherapy solution is externally heated and recirculated at a constant temperature via a catheter irrigation channel to deliver hyperthermia to the bladder wall by conduction. ${ }^{72}$ Previous to its application in the treatment of NMIBC, conductive hyperthermia was adopted as hyperthermic intraperitoneal chemotherapy (HIPEC), which is an approved treatment used in combination with cytoreductive surgery for peritoneal metastasis in ovarian, gastric, and colorectal cancer. ${ }^{73-75}$

Two conductive hyperthermic chemotherapy systems for bladder cancer have been reported, both of which use MMC: the Combat Bladder Recirculating System (BRS) and the Unithermia system. Minimal nursing 'hands-on' time is required once the system is set-up as a midtreatment repeat instillation of MMC is not required compared to the RITE system allowing. This allows for a lower nurse to patient ratio when treatment is being administered. The Combat BRS system uses a $16 \mathrm{Fr}$ three-way Foley catheter, which recirculates MMC in a close system with a bubble trap (Figure 2). MMC is heated to $43^{\circ} \mathrm{C}$ using an aluminium heat 
exchanger that enables efficient heat transfer and accurate temperature control within \pm 0.5 ${ }^{\circ} \mathrm{C}$. Each treatment uses 40 or $80 \mathrm{mg} \mathrm{MMC} \mathrm{in} 50 \mathrm{ml}$ of water for adjuvant and ablative treatment respectively recirculating for a continuous 60 minutes. ${ }^{32,72,76}$ The Unithermia system uses a conical heat exchanger with a high recirculation rate to deliver hyperthermic MMC to the bladder via an $18 \mathrm{Fr}$ Foley catheter. $\mathrm{MMC}$ is heated to $46.5^{\circ} \mathrm{C}$ to deliver it at $44.5^{\circ} \mathrm{C}$ to the bladder wall. The system is primed with $40 \mathrm{mg}$ of MMC in $50 \mathrm{ml}$ of water, which is recirculated for a continuous 50 minutes. ${ }^{33,76}$ Results of a pharmacokinetics study suggested that peak plasma MMC concentration is achieved around 45 minutes after MMC instillation. 77

Aqueous doxorubicin has been shown to efficacious for the treatment of NMIBC. ${ }^{78}$ The synergism between hyperthermia and temperature activated liposomes have been shown to enable a much higher dose of drug to be delivered at the target organ of treatment. ${ }^{79}$ ThermoDox is a heat-activated liposomal encapsulation of doxorubicin that is a promising alternative to $\mathrm{MMC}$. At $40-45^{\circ} \mathrm{C}$; the liposomes release doxorubicin directly at the heated source, which enables a targeted approach. ${ }^{80}$ An in vivo study in pigs showed that intravenous ThermoDox with localized conductive hyperthermia delivered to the bladder resulted in the 10fold higher concentration of doxorubicin within the bladder than when ThermoDox was not heated or intravenous doxorubicin. ${ }^{80}$ Although heat-activated, ThermoDox is infused intravenously and patients with a history of cardiac disease may not be suitable candidates for this therapy owing to the cardiotoxic nature of doxorubicin although reports suggest that this is less apparent in the liposomal based formulation..$^{81,82}$

Five studies have reported results for conductive hyperthermia, ${ }^{3272763383}$ and, although RCTs are in progress, level 1 evidence reporting outcomes for conductive hyperthermia for the treatment for NMIBC is lacking.

\section{[H2] Efficacy}

All reports to date are single-arm observational studies; two using the HIVEC system ${ }^{32,72}$ and three using the Unithermia system ${ }^{33,76,83}$, all of which use MMC (Table 3). All studies conducted to date included patients with predominantly intermediate-risk NMIBC and were proof-ofconcept studies with a limited sample size of between 15 and 43 patients. Studies using the HIVEC system report a RFS of $87.5 \%$ at the 24-month follow-up point in an adjuvant setting $(n=16)^{32}$ and a complete response rate of $60-63 \%$ after 8 once weekly ablative intravesical treatments $(n=39) .{ }^{32,72}$ The three studies using the Unithermia system included 117 patients and report RFS of $65-70 \%$ at follow-up points between $24-41$ months. ${ }^{33,76,83}$ These studies included one retrospective propensity score matched comparison ${ }^{83}$, which reported that BCG treated patients had a better RFS compared to conductive hyperthermia $(89.5 \%$ versus $70.1 \%, P=0.054) .{ }^{83}$ No difference in disease progression was reported.

\section{[H2] Adverse events}

Similar to RITE, conductive hyperthermia therapy is well tolerated and most adverse events are short lived (Table 4) ${ }^{86}$ Reliable adverse event data are available for the HIVEC system. 
An interim analysis of adverse events in 307 patients recruited into HIVEC-I and HIVEC-II reported that $89 \%$ of patients completed a minimum of induction therapy compared with $95 \%$ of patients treated with passive MMC. ${ }^{86}$ In the patients treated with HIVEC, the most common adverse events were urinary frequency $(15 \%)$, suprapubic pain $(13.1 \%)$, haematuria $(11.8 \%)$, and urinary urgency (11.8\%). ${ }^{86}$ HIVEC was associated with significantly increased incidence of urinary frequency $(15.0 \%$ versus $5.8 \%, p=0.008)$, haematuria $(11.8 \%$ versus $3.9 \%$, $\mathrm{p}=0.010)$, and bladder spasm (6.5\% versus $0.6 \%, p=0.006)$. No significant difference in grade III adverse events between HIVEC (2.3\%) and passive MMC (1.5\%) were observed, and these were predominantly caused by allergic reactions. No urethral strictures occurred in either treatment arm. ${ }^{86}$

The safety and efficacy data for the Unithermia system is not well reported and at present the grade III adverse event rate is $12 \%$ (Table 5$)$. Non-infective cystitis $(37.2 \%)$ is the predominant reported adverse event followed by suprapubic pain (23.3\%) and bladder spasm/ urinary urgency (22.1\%). Notably, one incidence of bladder perforation occurred following Unithermia treatment, resulting in a grade IV adverse event, which was reported by Ekin and colleagues. ${ }^{33}$ Reasons for this remained uncertain but may be related to the higher circulation rate of fluid and temperature used.

Prospective randomised data are eagerly awaited. HIVEC-I (EudraCT: 2013-002628-18) ${ }^{84}$ and HIVEC-II (ISRCTN: 23639415$)^{85}$ are two multicentre, open-label, phase II RCTs recruiting patients from 12 Spanish and 13 UK centres respectively.. HIVEC-I will randomize 303 patients with intermediate-risk disease to passive MMC, conductive hyperthermic MMC for 30 mins, or conductive hyperthermic MMC for 60 minutes. ${ }^{84}$ HIVEC-II will randomize 259 patients with intermediate-risk disease to passive MMC or conductive hyperthermic MMC for 60 mins. ${ }^{85}$ Both studies have completed patient recruitment at the end of 2017 and results are eagerly awaited.

\section{[H1] EMDA MMC}

EMDA enhances the delivery of chemotherapy by electro-osmosis, iontophoresis, and electroporation whereby an electrical charge is generated between a catheter electrode and a cutaneous electrode to aid the transport of drug molecules into tissues. ${ }^{87,88}$ In vitro studies have shown that EMDA MMC delivers a sixfold greater concentration of MMC to the bladder wall than passive diffusion, reaching a peak concentration of $\mathrm{MMC}$ within 15 minutes of initiating treatment ${ }^{87,88} \mathrm{MMC}$ was detected in all layers of the bladder wall in both treatments modalities; however, MMC concentration in the urothelium was 30 times greater using EMDA MMC than passive MMC, and threefold greater in the lamina propria and muscularis. ${ }^{87}$

Intravesical EMDA MMC is administered using a battery-powered generator to deliver a controlled electric current of up to $30 \mathrm{~mA} .{ }^{48}$ The electrical current passes between the intravesical active electrode at the tip of a catheter to a dispersive ground electrode positioned on the lower abdomen (Figure 3). The specialized 16 Fr catheter is in inserted and the bladder is washed with water, after which $40 \mathrm{mg} \mathrm{MMC}$ in $100 \mathrm{ml}$ of water is instilled with the operating current maintained at $20 \mathrm{~mA}$ pulsed electrical current. Treatment time is 30 minutes per session, which is shorter than RITE and conductive hyperthermia and cadaveric studies 
suggest that the peak concentration of MMC in the bladder wall is achieved after 15 minutes of initiating treatment. ${ }^{89}$

\section{[H2] Efficacy}

To date, seven studies have reported on the efficacy of EMDA MMC for bladder cancer, three of which investigated neoadjuvant EMDA MMC as monotherapy or in combination with $\mathrm{BCG}^{48,90,91}$ and a four studies in the adjuvant setting ${ }^{92-95}$ (Table 6). Four studies reported outcomes for monotherapy EMDA MMC, ${ }^{48,90,91,94,95}$ including one RCT in the neoadjuvant setting ${ }^{90}$ and one in the adjuvant setting. ${ }^{94}$

Alternating BCG with EMDA MMC is a more established regimen than EMDA MMC as monotherapy, and promising results from a RCT and another single-arm study have been reported. ${ }^{92,93}$ Di Stasi et al. ${ }^{93}$ randomized patients with high-risk NMIBC to either sequential BCG plus EMDA MMC or BCG alone. DFS was higher in the BCG plus EMDA MMC group than the BCG alone group at 88 months $(58.1 \%$ versus $42.1 \%, P=0.0012) .{ }^{93}$ Progressionfree survival $(90.7 \%$ versus $78.1 \%, P=0.004)$ and overall survival $(78.5 \%$ versus $67.6 \%, P=$ 0.045) were also significantly improved in BCG plus EMDA MMC cohort. However, the BCG plus EMDA MMC arm had an induction protocol of 9 once weekly treatment compared with the 6 once weekly treatments in the BCG alone arm and the increased number of induction treatments might have improved efficacy. A subsequent single-arm study using the same BCG plus EMDA MMC treatment regimen reported a $71 \%$ RFS and 95\% PFS at 24 months. ${ }^{92}$ The proposed hypothesis for combination therapy is that instilling BCG first results in BCG-induced inflammation, which might increase urothelium permeability to MMC. The results for BCG plus EMDA MMC are impressive, but further validation is required before it is accepted as standard of care.

In the monotherapy setting, a three-arm study randomized patients to either EMDA MMC, $B C G$, or passive MMC. ${ }^{94}$ Patients treated with EMDA MMC had a significantly longer time to recurrence than those who received passive MMC or BCG (EMDA MMC: 35 months versus MMC: 20 months versus BCG: 26 months, $P=0.013)$. However, no difference in time to disease progression was observed. Complete response rate at 6 months was higher in the EMDA MMC (58\%) and BCG (64\%) groups than in passive MMC group $(31 \%)(P=0.012)$.

Di Stasi et al. ${ }^{90}$ reported outcomes of a trial in which patients were randomized to either TURBT alone, preoperative EMDA MMC followed by TURBT, or TURBT with a single postoperative instillation of passive MMC. ${ }^{90}$ At a median follow-up point of 86 months, patients in the preoperative EMDA MMC group had significantly higher RFS than those in the TURBT alone and TURBT with postoperative passive MMC groups (62\% versus $36 \%$ versus $41 \%, P$ <0.0001). ${ }^{90}$ Colombo et al. ${ }^{48}$ compared ablative treatment with RITE, passive MMC, and EMDA MMC in a nonrandomized study, which showed that complete response rate was $66 \%$, $27.7 \%$, and $40 \%$ respectively. 48

[H2] Adverse events 
Similar to hyperthermia delivery systems, $90 \%$ of patients complete adjuvant induction treatment of EMDA MMC (Table 7). In a RCT comparing EMDA MMC, passive MMC, and $B C G$, significantly more local and systemic adverse events occurred in patients who received BCG than those in the two MMC arms. ${ }^{94}$ EMDA MMC had lower drug-related cystitis incidence (36\% versus $67 \%, p=0.001)$, haematuria ( $22 \%$ versus $72 \%, p=0.001)$, frequency $(19 \%$ versus $58 \%, \mathrm{p}=0.001)$, and fatigue $(2.5 \%$ versus $44.4 \%, \mathrm{p}=0.001)$ than $\mathrm{BCG} .{ }^{94}$ Pooled adverse events from 73 patients suggest that drug related cystitis and/or storage LUTS (23\%), bladder spasm (19\%), and haematuria (12\%) were the most common adverse events and no urethral strictures were reported. ${ }^{91,94,95}$ The most common reason for stopping EMDA MMC treatment was allergic reaction. ${ }^{93}$ Compared with RITE plus MMC , EMDA MMC has an increased rate of suprapubic pain and dysuria, and patients who received RITE patients experienced less urinary frequency.$^{48}$ Anecdotally, subcutaneous burns have been reported to develop where the ground electrode pad is placed.

No difference in reported adverse events were seen when sequential therapy of BCG-EMDA MMC was compared with BCG. ${ }^{93}$ Between $3 \%$ and $28 \%$ of patients treated with combination BCG and EMDA MMC could not tolerate the complete course of nine induction instillations. ${ }^{92,93}$ LUTS, haematuria, and inability to tolerate catheter were the most frequent reasons for early termination of treatment. ${ }^{92}$

Despite level one evidence reporting the superiority of EMDA, particularly when used in combination with BCG, compared to BCG and $\mathrm{MMC}$, the use of EMDA has been limited in the treatment of NMIBC. A Cochrane review highlights that the quality of evidence in these studies were low and data on time to recurrence and progression as well as adverse events remains inconclusive suggesting that further studies are warranted. ${ }^{96}$

\section{[H1] Comparison of cost between treatments}

Comparison of the estimated cost of treatment (disposables and drugs) between the different intravesical device assisted therapies based on end-user price suggest that that RITE treatment is the most costly followed by EMDA and conductive hyperthermia systems (Table 8). Estimated cost of treatment was based on published treatment protocols. Cost of precuring the different devices itself as well as the service contract if applicable are normally the subject of separate negotiation and has not been reported herein. Physician and nurse cost to deliver treatment and other associated cost have been excluded.

The disposables for the RITE and EMDA systems are more costly than those for conductive hyperthermic chemotherapy owing to the requirement of specialized catheters such as a radiofrequency antenna with thermocouples in the RITE catheter or active electrode at the catheter tip in the EMDA catheter. The different maintenance protocols used between different treatment devices makes comparison of cost difficult.

The only cost-effectiveness analysis that has been performed was reported in the RCT comparing BCG plus EMDA MMC with BCG alone. ${ }^{93}$ Based on a Markov model, sequential therapy was more costly than BCG therapy alone, but it was more efficacious with a 5-year increment cost-effectiveness ratio (ICER) of Can $\$ 27,815$ per life-year gained (US $\$ 21,173$, assuming Can $\$ 1=\mathrm{US} \$ 0.76) .{ }^{97}$ This figure is below the maximum acceptable ICER of $£ 20,000$ $£ 30,000$ (US\$26,472-US\$39,709, assuming $£ 1=U S \$ 1.32$ ) per quality-adjusted life-year 
(QALY) used by the UK National Institute for Health and Care Excellence (NICE) and the US $\$ 50,000$ QALY used as a benchmark of acceptability when evaluating new technology. ${ }^{98,99}$

\section{[H1] Novel agents}

Several novel technologies have been reported and are at an early phase development. Two devices augment the cytotoxic effects of chemotherapy by prolonging exposure time. GemRIS is an intravesical gemcitabine depot delivery system (225 mg), which is constructed from silicone tubing and nitinol wire. ${ }^{18}$ GemRIS is delivered into the bladder using an 18 Fr ureteric catheter-like inserter. The $5 \mathrm{~cm}$-long device, which folds into a pretzel shape, remains in the bladder and releases gemcitabine by passive diffusion over a 7-day period (Figure 4). ${ }^{18}$ The device can be removed 7 days later by grasping forceps and flexible cystoscopy. ${ }^{18}$ In a phase 1b study (NCT02722538), ${ }^{100}$ the GemRIS pretzel was well tolerated by all 10 patients with MIBC. Neoadjuvant GemRIS treatment for 14 days before radical cystectomy for all 10 patients resulted in a reduction of tumour size in $80 \%$ of patients with $40 \%$ having pT0 disease after treatment. ${ }^{18}$

VesiGel is a reverse-thermal gelation hydrogel compound combined with high-dose MMC that is liquid at room temperature and fully solidifies to a gel state at body temperature within 15 minutes after instillation. VesiGel can be delivered using a standard Foley catheter and gradually dissolves over several hours while releasing MMC. This slow release preparation might be more effective than a single 1 hour instillation of aqueous MMC. In a study of 64 patients with low-grade NMIBC treated with either VesiGel 0.06\% (40 mg at $64 \mathrm{ml}$ ), VesiGel $0.12 \%$ (80 $\mathrm{mg}$ at $64 \mathrm{ml}$ ), or MMC $0.1 \%$ (40 mg in $40 \mathrm{ml}$ ) as chemoablation therapy, VesiGel $80 \mathrm{mg}$ had a higher complete response rate (87.5\%) than aqueous MMC 40mg (63.6\%) and VesiGel $40 \mathrm{mg}(35.3 \%) .{ }^{19}$ The results of this proof-of-concept study are promising and future studies will be necessary to determine the effect of drug delivery and RFS in the adjuvant setting. ${ }^{19}$ Although results for VesiGel $80 \mathrm{mg}$ are promising, interestingly, aqueous MMC 40 $\mathrm{mg}$ had a better complete response rate than VesiGel $40 \mathrm{mg}$, suggesting that a slow-release formulation might take longer to reach peak chemotherapy concentration and this delay might negate the advantage of prolonged drug exposure, requiring an increased drug concentration. Early safety and tolerability data suggest that VesiGel is well tolerated with similar reports of allergic reaction to aqueous MMC, although the incidence of dysuria was higher ( $40 \%$ versus $13 \%) .101$

\section{[H1] Conclusions}

Intravesical hyperthermia-inducing device-assisted therapies are attractive treatment options for augmenting the efficacy of intravesical chemotherapy for the treatment of NMIBC. Prospective randomized trials for RITE suggest that it might be superior to BCG in papillary only-disease both in the BCG-naive and BCG-failure cohorts. However, results remain inconclusive for patients with isolated CIS or papillary disease with concurrent CIS. RCTs comparing conductive hyperthermia plus MMC with passive MMC alone have reached their recruitment target and results are eagerly awaited before adoption of intravesical deviceassisted therapies in clinical practice can be recommended. Results of RCTs of BCG-EMDA 
MMC, both in the ablative (neoadjuvant) and adjuvant setting, are impressive but this modality has not been widely adopted and will require further validation. Reported adverse events suggest that they are short lived and not significantly worse than intravesical BCG. Hence, these treatments are normally administered in a nurse-led environment. The induction regime of these treatments is now standardized to mirror traditional intravesical chemotherapy and BCG, but the maintenance treatment requirement and protocol has considerable variation. Other novel treatment options that increase intravesical chemotherapy contact time have shown promising results in phase I trials. With the issues with BCG supply in some countries the use of device-assisted therapies is expected to increase.

\section{Key points}

- Intravesical chemotherapy and BCG is the recommended adjuvant treatment for nonmuscle-invasive bladder cancer (NMIBC) to reduce the risk of disease recurrence.

- The combination BCG supply shortage and alternative bladder-sparing approaches in patients with BCG-refractory disease have led to the development of hyperthermiainducing device-assisted therapies for NMIBC.

- Radiofrequency induced thermotherapy (RITE), hyperthermic conductive chemotherapy, and electromotive drug administration (EMDA) chemotherapy are the most widely used devices to augment intravesical chemotherapy.

- Randomized controlled trials suggest that RITE and alternating BCG and EMDA mitomycin $C$ is more efficacious than BCG alone. Data on patients with concurrent carcinoma in situ treated with RITE is currently inconclusive.

- Adverse events from RITE, hyperthermic conductive chemotherapy, and EMDA chemotherapy are short lived and better tolerated than BCG.

- Other novel therapies that improve the delivery of chemotherapy by prolonging chemotherapy exposure time or targeted local therapy are promising.

\section{Review criteria}

A comprehensive literature review was performed using Medline Pubmed and Google Scholar. The following MESH words were used: 'non-muscle invasive bladder cancer', 'hyperthermia', 'chemohyperthermia', 'hyperthermia', 'radiofrequency induced thermotherapy', 'RITE', 'EMDA', 'electromotive drug administration', 'mitomycin', 'MMC', 'intravesical chemotherapy', 'device assisted' and 'novel agents'. Original research, review articles, editorials, commentaries and letters to the editor which were in English were used for this review. The reference list of articles was screened to identify additional articles.

\section{Acknowledgements}

We thank the Urology Foundation (W.S.T.), Mason Medical Research Foundation (W.S.T.) Medical Research Council (J.D.K.), and UCLH Biomedical Research Centre (J.D.K.) for funding our work. 
539

540

541

542

543

544

545

546

547

548 Publisher's note

549

550

551

\section{Author contributions}

W.S.T. performed the researched data for and wrote the manuscript. JDK contributed substantially to writing, reviewing, and editing of the manuscript before submission

\section{Competing interests statement}

J.D.K. is chief investigator for HYMN and HIVEC-II, which are trials using hyperthermia delivery systems to treat bladder cancer, and is a consultant for Combat Medical. W.S.T. declares no completing interests

Springer Nature remains neutral with regard to jurisdictional claims in published maps and institutional affiliations. 
553 Table 1: Overview of studies reporting outcomes using RITE for the treatment of NMIBC

554

\begin{tabular}{|c|c|c|c|c|c|c|c|c|c|c|}
\hline Study & $\begin{array}{c}\text { Patient } \\
\text { entry }\end{array}$ & $\begin{array}{c}\text { Number of } \\
\text { patients }\end{array}$ & $\begin{array}{l}\text { Risk group (previous } \\
\text { intravesical treatment) }\end{array}$ & Carcinoma in situ & $\begin{array}{l}\text { Median follow up, } \\
\text { months (Interquartile } \\
\text { range) }\end{array}$ & $\begin{array}{l}\text { Induction treatment } \\
\text { details }\end{array}$ & Maintenance & $\begin{array}{l}\text { RFS and complete } \\
\text { response rate } \\
\text { (where specified) }\end{array}$ & $\begin{array}{l}\text { Progression-free } \\
\text { survival }\end{array}$ & Refs \\
\hline $\begin{array}{l}\text { RCT of adjuvant RITE } \\
\text { versus institutional } \\
\text { standard practice }\end{array}$ & 2010- 2013 & $\begin{array}{l}\text { 104: } \\
\text { RITE: } 48 \\
\text { Control: } 56\end{array}$ & $\begin{array}{l}\text { Intermediate-risk (10\%) or } \\
\text { high-risk (90\%) with } \\
\text { recurrence following BCG, } \\
\text { unwilling or unfit for } \\
\text { cystectomy (previous } \\
\text { intravesical treatment: 100\%) }\end{array}$ & $68 \%$ & $35.1(23.1-44.5)$ & $\begin{array}{l}\text { RITE: } 6 \text { once weekly } \\
\text { with } 20 \text { plus } 20 \mathrm{mg} \\
\text { MMC in } 50 \mathrm{ml} \text { water for } \\
60 \text { mins } \\
\text { Control: } 6 \text { once weekly } \\
\text { BCG in } 50 \mathrm{ml} \text { saline or } \\
\text { standard of care at } \\
\text { institution (EMDA } \\
\text { chemotherapy, } \\
\text { gemcitabine, re- } \\
\text { challenge with MMC) }\end{array}$ & $\begin{array}{l}\text { RITE: } 20 \text { plus } 20 \mathrm{mg} \\
\text { MMC in } 50 \mathrm{ml} \text { water } \\
\text { oncee } 6 \text { weekly (year } \\
\text { 1) then once } 8 \text { weekly } \\
\text { (year 2) } \\
\text { Control: } 3 \text { weekly } \\
\text { instillations at } 3,6 \text {, } \\
12,18 \text {, and } 24 \\
\text { months }\end{array}$ & $\begin{array}{l}\text { Overall } 2 \text { year RFS: } \\
\text { RITE: } 34 \% \\
\text { Control: } 32 \% \\
\text { ( } p=0.24) \\
3 \text { month CR: } \\
\text { RITE: } 30 \% \\
\text { Control: } 47 \% \\
\text { ( } p=0.15)\end{array}$ & $\begin{array}{l}\text { RITE: } 83 \% \\
\text { Control: } 87 \%\end{array}$ & 47 \\
\hline
\end{tabular}




\begin{tabular}{|c|c|c|c|c|c|c|c|c|c|c|}
\hline $\begin{array}{l}\text { RCT of adjuvant RITE } \\
\text { versus BCG }\end{array}$ & $2002-2011$ & $\begin{array}{l}\text { 190: } \\
\text { RITE: } 92 \\
\text { BCG: } 98\end{array}$ & $\begin{array}{l}\text { Intermediate-risk (69\%) or } \\
\text { high-risk (31\%) risk BCG-naive } \\
\text { (previous intravesical } \\
\text { treatment: 11.1\%) }\end{array}$ & $23 \%$ & $24(24)$ & $\begin{array}{l}\text { RITE: } 6 \text { once weekly } 20 \\
\text { plus } 20 \mathrm{mg} \text { MMC in } 50 \\
\text { ml water for } 60 \text { mins } \\
\text { BCG: } 6 \text { once weekly } \\
\text { OncotICE full dose for } 2 \\
\text { hours }\end{array}$ & $\begin{array}{l}\text { RITE: } 20 \text { plus } 20 \mathrm{mg} \\
\text { MMC in } 50 \mathrm{ml} \text { once } \\
\text { weekly at } 6 \text { week } \\
\text { intervals } \\
\text { BCG: } 3 \text { once weekly } \\
\text { at } 3,6 \text {, and } 12 \\
\text { months }\end{array}$ & $\begin{array}{l}\text { Papillary only RFS : } \\
\text { RITE:81.8\%, BCG: } \\
64.8 \%(p=0.08) \\
\\
\text { CR for CIS at } 3 \\
\text { months: RITE: } \\
\text { 88.9\%, BCG: } 85.6 \% \\
(p=1)\end{array}$ & $\begin{array}{l}\text { RITE: } 0 \% \\
\text { BCG: } 1.4 \%\end{array}$ & 53 \\
\hline $\begin{array}{l}\text { Single-arm adjuvant } \\
\text { or ablative RITE }\end{array}$ & 2003-2009 & $\begin{array}{l}\text { 21: } \\
11 \text { ablative } \\
10 \text { adjuvant }\end{array}$ & $\begin{array}{l}\text { Intermediate-risk or high-risk } \\
(>57 \%) \text { recurrent NMIBC } \\
\text { (previous intravesical } \\
\text { treatment: } 71 \%)\end{array}$ & $38 \%$ & $\begin{array}{c}50 \\
\text { (range: } 1-120)\end{array}$ & $\begin{array}{l}\text { Ablative: } 12 \text { once } \\
\text { weekly } 40 \text { plus } 40 \mathrm{mg} \\
\text { MMC in } 50 \mathrm{ml} \text { saline } \\
\text { over } 60 \mathrm{mins} \\
\text { Adjuvant: } 6 \text { once weekly } \\
20 \text { plus } 20 \mathrm{mg} \text { MMC in } \\
50 \mathrm{ml} \text { saline over } 60 \\
\text { mins }\end{array}$ & NA & Overall RFS: $29 \%$ & Overall: $62 \%$ & 61 \\
\hline $\begin{array}{l}\text { Single-arm adjuvant } \\
\text { RITE }\end{array}$ & NA & 26 & $\begin{array}{l}\text { High-risk (previous intravesical } \\
\text { treatment not recorded) }\end{array}$ & $23 \%$ & $16.4(6-48)$ & $\begin{array}{l}6 \text { once weekly } 20 \text { plus } \\
20 \mathrm{mg} \text { in } 50 \mathrm{ml} \mathrm{saline} \mathrm{for} \\
60 \mathrm{mins}\end{array}$ & $\begin{array}{l}6 \text { once monthly } 20 \\
\text { plus } 20 \mathrm{mg} \text { in } 50 \mathrm{ml} \\
\text { saline }\end{array}$ & RFS: $88.4 \%$ & NA & 54 \\
\hline $\begin{array}{l}\text { Single-arm adjuvant } \\
\text { RITE }\end{array}$ & 2006-2010 & 42 & $\begin{array}{l}\text { High-risk (previous intravesical } \\
\text { treatment: } 64 \% \text { ) }\end{array}$ & $7 \%$ & $38(4-73)$ & $\begin{array}{l}4 \text { once weekly then } 6 \\
\text { two weekly } 40 \text { plus } 40 \\
\mathrm{mg} \text { of } \mathrm{MMC} \text { in } 50 \mathrm{ml} \\
\text { water for } 60 \mathrm{mins}\end{array}$ & $\begin{array}{l}4 \text { once monthly } 40 \\
\text { plus } 40 \mathrm{mg} \mathrm{MMC} \text { in } 50 \\
\mathrm{ml} \text { water }\end{array}$ & RFS: $57.1 \%$ & $88 \%$ & 55 \\
\hline
\end{tabular}




\begin{tabular}{|c|c|c|c|c|c|c|c|c|c|c|}
\hline $\begin{array}{l}\text { Single-arm adjuvant } \\
\text { or ablative RITE }\end{array}$ & 2006- 2009 & $\begin{array}{l}\text { 30: } \\
14 \text { ablative } \\
16 \text { adjuvant }\end{array}$ & $\begin{array}{l}\text { High risk (previous } \\
\text { chemotherapy } 57 \% \text {, previous } \\
\text { BCG 43\%) }\end{array}$ & $13 \%$ & Mean: $14 \pm 8.5$ & $\begin{array}{l}\text { Ablative: } 8 \text { once weekly } \\
40 \text { plus } 40 \mathrm{mg} \text { MMC in } \\
50 \mathrm{ml} \text { water over } 60 \\
\text { mins } \\
\text { Adjuvant: } 6 \text { once weekly } \\
20 \text { plus } 20 \mathrm{mg} \text { MMC in } \\
50 \mathrm{ml} \text { water over } 60 \\
\text { mins }\end{array}$ & $\begin{array}{l}\text { Ablative: } 6 \text { once } \\
\text { monthly } 40 \text { plus } 40 \\
\text { mg MMC in } 50 \mathrm{ml} \\
\text { Adjuvant: } 6 \text { once } \\
\text { monthly } 20 \text { plus } 20 \\
\text { mg MMC in } 50 \mathrm{ml} \\
\text { water }\end{array}$ & $\begin{array}{c}\text { Ablative CR: } 42.9 \% \\
\text { Adjuvant RFS: } \\
43.8 \%\end{array}$ & $\begin{array}{l}\text { Ablative: } 82.4 \% \\
\text { Adjuvant: } 0 \%\end{array}$ & 62 \\
\hline $\begin{array}{l}\text { Single-arm adjuvant } \\
\text { and ablative RITE }\end{array}$ & 2001-2011 & $\begin{array}{l}92: \\
26 \text { ablative } \\
66 \text { adjuvant }\end{array}$ & $\begin{array}{l}\text { Intermediate-risk (27\%) or } \\
\text { high-risk(73\%) (previous } \\
\text { intravesical treatment: } 76 \%)\end{array}$ & $28 \%$ & 23 (range: $3-84$ ) & $\begin{array}{l}\text { Ablative: } 8 \text { once weekly } \\
40 \text { plus } 40 \mathrm{mg} \text { MMC in } \\
50 \mathrm{ml} \text { water over } 60 \\
\text { mins } \\
\text { Adjuvant: } 6 \text { once weekly } \\
20 \text { plus } 20 \mathrm{mg} \text { MMC in } \\
50 \mathrm{ml} \text { water over } 60 \\
\text { mins }\end{array}$ & $\begin{array}{l}\text { Adjuvant: } 6 \text { once } \\
\text { every } 6 \text { weeks } 20 \text { plus } \\
20 \mathrm{mg} \text { MMC in } 50 \mathrm{ml} \\
\text { water }\end{array}$ & $\begin{array}{c}\text { Ablative CR: } 79 \% \\
\text { Adjuvant RFS: } 72 \%\end{array}$ & $\begin{array}{c}\text { Ablative: NA } \\
\text { Adjuvant: } 95.3 \%\end{array}$ & 63 \\
\hline $\begin{array}{l}\text { RCT of adjuvant RITE } \\
\text { versus MMC }\end{array}$ & 1994-1999 & $\begin{array}{l}83: \\
\text { RITE: } 42 \\
\text { MMC: } 41\end{array}$ & $\begin{array}{l}\text { Intermediate-risk and high-risk } \\
\text { (>61\%) (previous intravesical } \\
\text { treatment: } 58 \% \text { ) }\end{array}$ & $1.2 \%$ & 91 (range: 6-154) & $\begin{array}{l}8 \text { once weekly } 20 \text { plus } \\
20 \mathrm{mg} \mathrm{MMC} 50 \mathrm{ml} \\
\text { water over } 60 \mathrm{mins}\end{array}$ & $\begin{array}{l}4 \text { once monthly } 20 \\
\text { plus } 20 \mathrm{mg} \text { MMC in } \\
50 \mathrm{ml} \text { water or } 60 \\
\mathrm{mins}\end{array}$ & $\begin{array}{l}\text { RITE RFS:60\%, } \\
\text { MMC: } 20 \% \\
\text { (p<0.001) }\end{array}$ & $\begin{array}{l}\text { RITE: } 95.1 \% \\
\text { MMC: } 92.9 \%\end{array}$ & 56 \\
\hline $\begin{array}{l}\text { Single-arm adjuvant } \\
\text { RITE }\end{array}$ & 2000-2007 & 56 & $\begin{array}{l}\text { High-risk } \\
\text { (previous intravesical } \\
\text { treatment: 43\%, previous BCG: } \\
33.9 \% \text { ) }\end{array}$ & $16 \%$ & 18 (range: $2-49$ ) & $\begin{array}{l}6 \text { once weekly } 20 \text { plus } \\
20 \text { mg MMC over } 60 \\
\text { mins }\end{array}$ & $\begin{array}{l}4-6 \text { once weekly } 20 \\
\text { plus } 20 \text { mg MMC for } \\
6 \text { treatments }\end{array}$ & RFS: $64.7 \%$ & $92.9 \%$ & 57 \\
\hline $\begin{array}{l}\text { Single-arm adjuvant } \\
\text { RITE }\end{array}$ & 2001-2008 & 111 & $\begin{array}{l}\text { High-risk papillary recurrence } \\
\text { after } B C G\end{array}$ & $0 \%$ & 16 (range: $2-74$ ) & $\begin{array}{l}6 \text { once weekly } 20 \text { plus } \\
20 \mathrm{mg} \mathrm{MMC} \mathrm{in} 50 \mathrm{ml} \\
\text { over } 60 \mathrm{mins}\end{array}$ & $\begin{array}{l}4-6 \text { once weekly } 20 \\
\text { plus } 20 \text { mg MMC for } \\
6 \text { treatments }\end{array}$ & $\begin{array}{l}12 \text { months RFS: } 85 \% \\
24 \text { months RFS: } 56 \%\end{array}$ & $97 \%$ & 58 \\
\hline
\end{tabular}




\begin{tabular}{|c|c|c|c|c|c|c|c|c|c|c|}
\hline $\begin{array}{l}\text { Single-arm adjuvant } \\
\text { or ablative RITE }\end{array}$ & $1997-2005$ & $\begin{array}{l}51: \\
33 \text { ablative } \\
18 \text { adjuvant }\end{array}$ & $\begin{array}{l}\text { High-risk: CIS with or without } \\
\text { papillary NMIBC (previous } \\
\text { BCG: 66.7\%) }\end{array}$ & $100 \%$ & 22 (range: $3-77$ ) & $\begin{array}{l}\text { Ablative (papillary lesion } \\
\text { and/or wide-spread } \\
\text { CIS): } 8 \text { once weekly } 40 \\
\text { plus } 40 \mathrm{mg} \text { MMC in } \\
50 \mathrm{ml} \text { water over } 60 \\
\text { mins } \\
\text { Adjuvant: } 6 \text { once weekly } \\
20 \text { plus } 20 \mathrm{mg} \text { MMC in } \\
50 \mathrm{ml} \text { water over } 60 \\
\text { mins }\end{array}$ & $\begin{array}{l}\text { Ablative: } 6 \text { once } \\
\text { monthly } 40 \text { plus } 40 \\
\text { mg MMC in } 50 \mathrm{ml} \\
\text { water } \\
\text { Adjuvant: } 6 \text { once } \\
\text { monthly } 20 \text { plus } 20 \\
\text { mg MMC in } 50 \mathrm{ml} \\
\text { water }\end{array}$ & $\begin{array}{l}\text { All-patient RFS: } 55 \% \\
\text { All-patient CR at } 4 \\
\text { months: } 92 \%\end{array}$ & $90 \%$ & 64 \\
\hline $\begin{array}{l}\text { Single-arm adjuvant } \\
\text { or ablative RITE }\end{array}$ & $2000-2004$ & $\begin{array}{l}\text { 47: } \\
10 \text { ablative } \\
22 \text { adjuvant }\end{array}$ & $\begin{array}{l}\text { Intermediate-risk (16\%) or } \\
\text { high-risk(84\%) } \\
\text { (previous prophylactic BCG: } \\
59 \% \text {; previous ablative BCG: } \\
80 \% \text { ) }\end{array}$ & $0 \%$ & 9.6 & $\begin{array}{l}\text { Ablative: } 8 \text { onceweekly } \\
40 \text { plus } 40 \mathrm{mg} \text { MMC in } \\
50 \mathrm{ml} \text { water } \\
\text { Adjuvant: } 6-8 \text { once } \\
\text { weekly } 20 \text { plus } 20 \mathrm{mg} \\
\text { MMC in } 50 \mathrm{ml} \text { water }\end{array}$ & $\begin{array}{l}\text { Ablative: } 4 \text { once } \\
\text { monthly } 40 \text { plus } 40 \\
\text { mg MMC in } 50 \mathrm{ml} \\
\text { water } \\
\text { Adjuvant: } 4-6 \text { once } \\
\text { monthly } 20 \text { plus } 20 \\
\mathrm{mg} \text { MMC in } 50 \mathrm{ml} \\
\text { water }\end{array}$ & $\begin{array}{l}\text { Ablative CR: } 80 \% \\
\text { Adjuvant RFS: } 91 \%\end{array}$ & $\begin{array}{c}\text { Ablative NA } \\
\text { Adjuvant 0\% }\end{array}$ & 65 \\
\hline $\begin{array}{l}\text { Adjuvant single arm } \\
\text { RITE }\end{array}$ & $1994-2003$ & 90 & $\begin{array}{l}\text { Intermediate-risk (59\%) or } \\
\text { high-risk (41\%) (previous BCG: } \\
46 \% \text { ) }\end{array}$ & $0 \%$ & 18 (range: $4-24$ ) & $\begin{array}{l}\text { Adjuvant: } 6-8 \text { once } \\
\text { weekly } 20 \text { plus } 20 \mathrm{mg} \text { in } \\
50 \mathrm{ml} \text { water }\end{array}$ & $\begin{array}{l}\text { Adjuvant: } 4-6 \text { once } \\
\text { monthly treatments }\end{array}$ & RFS: 84\% & $0 \%$ & 59 \\
\hline $\begin{array}{l}\text { Single-arm adjuvant } \\
\text { and ablative RITE }\end{array}$ & NA & $\begin{array}{l}52: \\
-28 \text { ablative } \\
-24 \text { adjuvant }\end{array}$ & High-grade & $0 \%$ & $\begin{array}{l}15.2 \text { (range: } 6-90) \text {, } \\
\text { mean: } 35.3 \text { months }\end{array}$ & $\begin{array}{l}\text { Ablative: } 8 \text { once weekly } \\
40 \text { plus } 40 \mathrm{mg} \mathrm{MMC} \mathrm{in} \\
50 \mathrm{ml} \text { water over } 40 \\
\text { mins } \\
\text { Adjuvant: } 8 \text { once weekly } \\
20 \text { plus } 20 \mathrm{mg} \text { MMC in } \\
50 \mathrm{ml} \text { water over } 40 \\
\mathrm{mins}\end{array}$ & $\begin{array}{l}\text { Ablative: } 4 \text { once } \\
\text { monthly } 40 \text { plus } 40 \\
\text { mg MMC in } 50 \mathrm{ml} \\
\text { water over } 40 \mathrm{mins} \\
\text { Adjuvant: } 4 \text { once } \\
\text { monthly } 20 \text { plus } 20 \\
\text { mg MMC in } 50 \mathrm{ml} \\
\text { water over } 40 \mathrm{mins}\end{array}$ & $\begin{array}{c}\text { Ablative CR: } 75 \% \\
\text { Adjuvant RFS: } \\
62.5 \%\end{array}$ & NA & 66 \\
\hline
\end{tabular}




\begin{tabular}{|c|c|c|c|c|c|c|c|c|c|c|}
\hline $\begin{array}{l}\text { RCT of adjuvant RITE } \\
\text { vs MMC }\end{array}$ & 1994-1999 & $\begin{array}{c}83 \text { (RITE: } 42 \\
\text { versus MMC: } \\
41 \text { ) }\end{array}$ & $\begin{array}{l}\text { Intermediate-risk or high-risk } \\
\text { (>61\%) (previous intravesical } \\
\text { treatment: 58\%) }\end{array}$ & $1.2 \%$ & 24 & $\begin{array}{l}\text { Both treatment arms: } \\
8 \text { once weekly } 20 \text { plus } \\
20 \mathrm{mg} \mathrm{MMC} 50 \mathrm{ml} \\
\text { water over } 60 \mathrm{mins} \text { in } \\
\text { both RITE and MMC } \\
\text { arms }\end{array}$ & $\begin{array}{l}\text { Both treatment arms: } \\
4 \mathrm{monthly} 20 \text { plus } 20 \\
\mathrm{mg} \text { MMC in } 50 \mathrm{ml} \\
\text { water over } 60 \mathrm{mins}\end{array}$ & $\begin{array}{l}\text { RFS: RITE: } 82.9 \% \\
\text { MMC: } 42.5 \% \\
\text { (p=0.0002) }\end{array}$ & $\begin{array}{l}\text { RITE: } 100 \% \\
\text { MMC: } 97.6 \%\end{array}$ & 60 \\
\hline $\begin{array}{l}\text { Single-arm ablative } \\
\text { RITE }\end{array}$ & 1996-1998 & $\begin{array}{l}80: \\
29 \text { RITE } \\
36 \mathrm{MMC} \\
15 \mathrm{EMDA}\end{array}$ & Low-risk & $0 \%$ & $\begin{array}{l}7-10 \text { days after } \\
\text { treatment }\end{array}$ & $\begin{array}{l}\text { All } 4 \text { once weekly: } \\
\text { MMC: } 40 \mathrm{mg} \text { in } 50 \mathrm{ml} \\
\text { saline } \\
\text { RITE: } 40 \mathrm{mg} \text { in } 50 \mathrm{ml} \\
\text { water } \\
\text { EMDA: } 40 \mathrm{mg} 150 \mathrm{ml} \\
\text { water }\end{array}$ & None & $\begin{array}{l}\text { CR: MMC: } 27.7 \% \text {, } \\
\text { RITE: } 66 \% \\
\text { EMDA: } 40 \%\end{array}$ & NA & 48 \\
\hline $\begin{array}{l}\text { Single-arm ablative } \\
\text { RITE }\end{array}$ & 1992-1996 & 19 & $\begin{array}{l}\text { High-risk (previous intravesical } \\
\text { treatment 100\%) }\end{array}$ & $0 \%$ & $\begin{array}{c}\text { CR: } 2 \text { weeks after } \\
\text { treatment }\end{array}$ & $\begin{array}{l}8 \text { once weekly } 40 \mathrm{mg} \text { in } \\
40 \mathrm{ml} \text { water for } 40 \mathrm{mins}\end{array}$ & None & CR: $47 \%$ & $100 \%$ & 49 \\
\hline $\begin{array}{l}\text { RCT of ablative RITE } \\
\text { versus MMC }\end{array}$ & 1989-1993 & $\begin{array}{l}\text { 52: } \\
\text { RITE: } 29 \\
\text { MMC: } 23\end{array}$ & $\begin{array}{l}\text { Intermediate-risk and high-risk } \\
(>7 \%) \%) \text { (previous intravesical } \\
\text { treatment: } 80.8 \% \text { ) }\end{array}$ & $0 \%$ & $\begin{array}{l}38 \\
36\end{array}$ & $\begin{array}{l}\text { Both treatment arms: } \\
6-8 \text { once weekly } 40+40 \\
\mathrm{mg} \mathrm{MMC} \mathrm{in} 50 \mathrm{ml} \text { water } \\
\text { for } 60 \mathrm{mins}\end{array}$ & None & $\begin{array}{l}\text { E } \\
\text { CR: RITE: } 66 \% \text {, } \\
\text { MMC: 22\% (p<0.01) } \\
\text { RFS: RITE: } 73 \%, \\
\text { MMC 61\% }(p>0.3)\end{array}$ & NA & 50 \\
\hline $\begin{array}{l}\text { Single-arm ablative } \\
\text { RITE }\end{array}$ & $1988-1992$ & 44 & $\begin{array}{l}\text { Intermediate-risk or high-risk } \\
(>27 \%) \text { (previous intravesical } \\
\text { treatment: } 63.6 \%)\end{array}$ & $0 \%$ & TURBT <3 weeks & $\begin{array}{l}8 \text { twice weekly (within } 6 \\
\text { weeks) } 30 \mathrm{mg} \text { MMC in } \\
60 \mathrm{ml} \text { water for } 60 \mathrm{mins}\end{array}$ & None & CR: $70.4 \%$ & NA & 44 \\
\hline $\begin{array}{l}\text { Single-arm ablative } \\
\text { RITE }\end{array}$ & NA & 12 & Not known & $0 \%$ & TURBT 1-3 weeks & $\begin{array}{l}\text { 6-8 once weekly } 30 \mathrm{mg} \\
\text { MMC in } 60 \mathrm{ml}\end{array}$ & None & CR: $41.7 \%$ & NA & 51 \\
\hline
\end{tabular}

555 CIS, carcinoma in situ; CR, complete response; DFS, disease-free survival; EMDA, electromotive drug administration; MMC, mitomycin C; NA, not applicable; NMIBC, non-

556 muscle-invasive bladder cancer; NS, not significant; RCT, randomized control trial; RITE, radiofrequency-induced thermochemotherapeutic effect; RFS, recurrence-free

557 survival; TURBT, transurethral resection of bladder tumour; 
Table 2 | Adverse events in patients with NMIBC treated with RITE

\begin{tabular}{|c|c|c|c|c|c|c|c|c|c|c|c|c|c|c|}
\hline First author & $\begin{array}{c}\text { Number of } \\
\text { patients }\end{array}$ & $\begin{array}{c}\text { Complete } \\
\text { treatment } \\
(\%)\end{array}$ & $\begin{array}{c}\text { Grade } \geq 3 \\
\text { adverse } \\
\text { events (\%) }\end{array}$ & $\begin{array}{l}\text { Haematuria } \\
\text { (\%) }\end{array}$ & $\begin{array}{l}\text { UTI or } \\
\text { sepsis } \\
\text { (\%) }\end{array}$ & $\begin{array}{c}\text { Suprapubic } \\
\text { pain (\%) }\end{array}$ & $\begin{array}{c}\text { Non- } \\
\text { infective } \\
\text { cystitis (\%) }\end{array}$ & $\begin{array}{c}\text { Bladder } \\
\text { spasmor } \\
\text { urgency } \\
\text { (\%) }\end{array}$ & $\begin{array}{c}\text { Stricture } \\
(\%)\end{array}$ & $\begin{array}{c}\text { Allergic } \\
\text { reaction } \\
(\%)\end{array}$ & $\begin{array}{c}\text { Incontinence } \\
\text { (\%) }\end{array}$ & $\begin{array}{l}\text { Nocturia } \\
\text { (\%) }\end{array}$ & $\begin{array}{l}\text { Reduced } \\
\text { bladder } \\
\text { capacity } \\
\text { (\%) }\end{array}$ & Refs \\
\hline Tan et al., 2016 & 48 & 90 & 10 & 48 & 23 & 58 & 54 & 61 & 6 & 15 & 21 & 60 & NR & 47 \\
\hline $\begin{array}{l}\text { Sooriakumaran et } \\
\text { al., } 2016\end{array}$ & 97 & 93 & 7 & 14 & 14 & 1 & 44 & 25 & 0 & 0 & NR & NR & NR & 52 \\
\hline $\begin{array}{l}\text { Kiss B et al., } 2015 \\
61\end{array}$ & 21 & 62 & 52 & 24 & 0 & 38 & 52 & 24 & 10 & 10 & NR & NR & NR & 61 \\
\hline $\begin{array}{l}\text { Maffezzini et al., } \\
201455\end{array}$ & 42 & 88 & 0 & 62 & 0 & 29 & 71 & 12 & 0 & 0 & 29 & NR & NR & 55 \\
\hline Volpe et al., 2012 & 30 & 100 & NR & 27 & 7 & 3 & 23 & 30 & 0 & 13 & NR & NR & 7 & 62 \\
\hline $\begin{array}{l}\text { Moskovitz et al., } \\
2012\end{array}$ & 92 & 96 & 4 & 7 & 1 & 29 & 3 & 22 & 5 & 1 & 4 & 9 & NR & 63 \\
\hline $\begin{array}{l}\text { Halachmi et al., } \\
2011^{57}\end{array}$ & 56 & 91 & NR & 4 & 00 & 13 & 18 & 23 & 2 & 12.5 & NR & NR & NR & 57 \\
\hline Nativ et al., $2009^{58}$ & 111 & 95 & 8 & 19 & 2 & 27 & 16 & 31 & 5 & 8 & 10 & 8 & NR & 58 \\
\hline $\begin{array}{l}\text { Moskovitz et al., } \\
2005\end{array}$ & 47 & NR & 4 & 17 & 00 & 66 & 6 & 17 & 6 & 4 & NR & NR & NR & 65 \\
\hline $\begin{array}{l}\text { van der Heijden et } \\
\text { al., } 200459\end{array}$ & 90 & 100 & NR & 9 & 00 & 37 & 24 & 0 & 4 & 9 & NR & NR & NR & 59 \\
\hline Gofrit et al., 2004 & 52 & 96 & NR & 2 & 10 & 23 & 58 & 15 & 2 & 10 & NR & NR & 10 & 66 \\
\hline $\begin{array}{l}\text { Colombo et al., } \\
2003\end{array}$ & 42 & 69 & NR & 7 & 0 & 20 & 24 & 0 & 7 & 12 & NR & NR & NR & 60 \\
\hline $\begin{array}{l}\text { Colombo et al., } \\
1996\end{array}$ & 29 & 93 & NR & NR & NR & NR & 100 & NR & 0 & NR & NR & 72 & NR & 50 \\
\hline $\begin{array}{l}\text { Colombo et al., } \\
1995\end{array}$ & 44 & NR & NR & NR & NR & NR & NR & NR & 2 & 2 & NR & NR & NR & ${ }^{44}$ \\
\hline Rigatti et al., 1991 & 12 & NR & NR & NR & NR & $25 \%$ & NR & 42 & 0 & NR & NR & NR & NR & 51 \\
\hline Total & 813 & 92.0 & 98.3 & 17.2 & 4.8 & 29.5 & 32.0 & 20.3 & 3.6 & 5.7 & 12.6 & 23.9 & 8.5 & NA \\
\hline
\end{tabular}

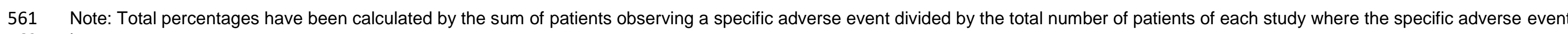
562 is report 
Table 3 | Outcomes of conductive hyperthermia for the treatment of NMIBC

\begin{tabular}{|c|c|c|c|c|c|c|c|c|c|c|}
\hline Setting & Patient entry & $\begin{array}{c}\text { Number of } \\
\text { patients }\end{array}$ & Risk group & Carcinoma in situ & $\begin{array}{l}\text { Median follow up, } \\
\text { months (IQR) }\end{array}$ & $\begin{array}{l}\text { Induction treatment } \\
\text { details }\end{array}$ & Maintenance & $\begin{array}{c}\text { RFS and complete } \\
\text { response rate (where } \\
\text { specified) }\end{array}$ & $\begin{array}{l}\text { Progression free } \\
\text { survival }\end{array}$ & Refs \\
\hline \multicolumn{11}{|l|}{ HIVEC } \\
\hline $\begin{array}{l}\text { Single-arm } \\
\text { adjuvant or } \\
\text { ablative }\end{array}$ & $2010-2015$ & $\begin{array}{l}40: \\
24 \text { ablative } \\
16 \text { adjuvant }\end{array}$ & $\begin{array}{l}\text { Intermediate-risk (35\%) } \\
\text { and high-risk (65\%) } \\
\text { (previous intravesical } \\
\text { treatment: } 73 \% \text { ) }\end{array}$ & $15 \%$ & $\begin{array}{l}\text { Ablative: } 37 \text { (95\% Cl: } \\
\text { 12-52) } \\
\text { Adjuvant: } 24 \text { (95\% Cl: } \\
\text { 9-32) }\end{array}$ & $\begin{array}{l}\text { Ablative: } 8 \text { once } \\
\text { weekly } 80 \mathrm{mg} \text { in } 50 \\
\mathrm{ml}\left(43^{\circ} \mathrm{C}\right) \text { in } 50 \mathrm{ml} \\
\text { water for } 60 \mathrm{mins} \\
\text { Adjuvant: } 4 \text { once } \\
\text { weekly } 40 \mathrm{mg} \text { in } 50 \\
\mathrm{ml}\left(43^{\circ} \mathrm{C}\right) 50 \mathrm{ml} \\
\text { water for } 60 \mathrm{mins}\end{array}$ & $\begin{array}{l}\text { Ablative: NA } \\
\text { Adjuvant: } 6 \text { monthly } \\
40 \mathrm{mg} \text { in } 50 \mathrm{ml}\end{array}$ & $\begin{array}{l}\text { Ablative: } \\
\text { CR:62.5\% } \\
48 \text { month RFS: } 79.2 \% \\
\text { Adjuvant: } \\
\text { RFS: } 87.5 \%\end{array}$ & NA & 32 \\
\hline Single-arm ablative & 2010- 2011 & 15 & $\begin{array}{l}\text { Intermediate }(27 \%) \text { and } \\
\text { high }(73 \%) \text { risk }(73 \% \\
\text { previous intravesical } \\
\text { treatment) }\end{array}$ & $0 \%$ & $\begin{array}{l}\text { TURBT 7-15 days } \\
\text { after neoadjuvant } \\
\text { treatment, } \\
29 \text { months ( } 95 \% \mathrm{Cl} \text { : } \\
\text { 26-32) follow-up } \\
\text { duration }\end{array}$ & $\begin{array}{l}8 \text { once weekly } 80 \mathrm{mg} \\
\text { in } 50 \mathrm{ml} \text { water }\left(43^{\circ} \mathrm{C}\right. \\
\text { for } 60 \mathrm{mins})\end{array}$ & NA & $\begin{array}{l}\text { CR: } 60 \% \\
\text { RFS: } 86.7 \%\end{array}$ & NA & 72 \\
\hline \multicolumn{11}{|l|}{ Unithermia } \\
\hline $\begin{array}{l}\text { Single-arm } \\
\text { adjuvant }\end{array}$ & 2009-2011 & 34 & $\begin{array}{l}\text { Low-risk, intermediate- } \\
\text { risk, or high-risk (24\%) } \\
\text { (all had recurrence } \\
\text { after induction BCG) }\end{array}$ & $0 \%$ & 41 & $\begin{array}{l}6 \text { once weekly } 40 \mathrm{mg} \\
\text { MMC in } 50 \mathrm{ml} \text { saline } \\
\left(43-45^{\circ} \mathrm{C}\right) \text { for } 45 \mathrm{mins}\end{array}$ & NA & RFS: $64.7 \%$ & $76.5 \%$ & 76 \\
\hline $\begin{array}{l}\text { Single-arm } \\
\text { adjuvant }\end{array}$ & 2011- 2013 & 43 & $\begin{array}{l}\text { Treatment-naive, high- } \\
\text { risk }\end{array}$ & $23 \%$ & $30(9-39)$ & $\begin{array}{l}6 \text { once weekly } 40 \mathrm{mg} \\
\text { MMC in } 50 \mathrm{ml} \text { of } \\
\text { saline ( } 43-45 \mathrm{C} \text { ) for } \\
60 \mathrm{mins}\end{array}$ & $\begin{array}{l}3 \text { once weekly } \\
\text { instillations at } 3 \text { and } 6 \\
\text { months }\end{array}$ & RFS: $67.5 \%$ & NA & 33 \\
\hline
\end{tabular}




\begin{tabular}{|c|c|c|c|c|c|c|c|c|c|c|}
\hline $\begin{array}{l}\text { Adjuvant } \\
\text { propensity scored } \\
\text { matched cohort } \\
\text { (versus BCG) }\end{array}$ & 2004-2014 & $\begin{array}{l}182: \\
\text { CH: } 40 \\
\text { BCG: } 142\end{array}$ & $\begin{array}{l}\text { Treatment-naive, high- } \\
\text { risk }\end{array}$ & $18 \%$ & 24 & $\begin{array}{l}\text { CH: } 6 \text { once weekly } 40 \\
\text { mg in } 50 \mathrm{ml} \text { saline } \\
\left(43-45^{\circ} \mathrm{C}\right) \text { for } 60 \text { mins } \\
\text { BCG: } 6 \text { weekly }\end{array}$ & $\begin{array}{l}\text { CH: } 3 \text { once weekly } \\
\text { instillations at } 3 \text { and } 6 \\
\text { months } \\
\text { BCG: determined by } \\
\text { clinician or patient }\end{array}$ & $\begin{array}{l}\text { RFS: CH: } 70.1 \%, \text { BCG: } \\
89.5 \% \\
\text { (univariate: } p=0.006 \text {, } \\
\text { multivariate: } \\
p=0.054 \text { ) }\end{array}$ & $\begin{array}{l}\text { CH: } 87.2 \% \\
\text { BCG: } 94.9 \%\end{array}$ & 83 \\
\hline
\end{tabular}

$\mathrm{CH}$, conductive hyperthermia; $\mathrm{CR}$, complete response; DFS, disease-free survival; RFS, recurrence-free survival; MMC, mitomycin C; NA, not applicable; RFS, recurrence free survival; TURBT, transurethral resection of the bladder tumour. 
581 Table 4: Adverse events in patients with NMIBC treated with conductive hyperthermia using HIVEC.

\begin{tabular}{|c|c|c|c|c|c|c|c|c|c|c|c|c|c|}
\hline $\begin{array}{c}\text { First } \\
\text { author }\end{array}$ & $\begin{array}{c}\text { Number of } \\
\text { patients }\end{array}$ & $\begin{array}{c}\text { Complete } \\
\text { treatment (\%) }\end{array}$ & $\begin{array}{c}\text { Grade } \geq 3 \\
\text { adverse } \\
\text { events (\%) }\end{array}$ & Haematuria (\%) & $\begin{array}{c}\text { UTI or } \\
\text { sepsis (\%) }\end{array}$ & $\begin{array}{c}\text { Suprapubic pain } \\
\text { (\%) }\end{array}$ & $\begin{array}{c}\text { Non- } \\
\text { infective } \\
\text { cystitis (\%) }\end{array}$ & $\begin{array}{c}\text { Bladder } \\
\text { spasm or } \\
\text { urgency (\%) }\end{array}$ & Stricture (\%) & $\begin{array}{c}\text { Allergic } \\
\text { reaction (\%) }\end{array}$ & $\begin{array}{c}\text { Urinary } \\
\text { retention (\%) }\end{array}$ & $\begin{array}{c}\text { Bladder } \\
\text { calcification (\%) }\end{array}$ & Refs \\
\hline $\begin{array}{l}\text { Sousa et } \\
\text { al., } 2016\end{array}$ & 40 & 98 & 8 & 23 & 23 & 28 & 40 & 33 & 3 & 3 & 8 & 3 & 32 \\
\hline $\begin{array}{l}\text { Sousa et } \\
\text { al, 2014 }\end{array}$ & 15 & NR & & 20 & 13 & 27 & 33 & 27 & 0 & 7 & 0 & 7 & 72 \\
\hline Total & 55 & 98 & 5.5 & 21.8 & 20.0 & 27.3 & 38.2 & 30.9 & 1.8 & 3.6 & 5.5 & 3.6 & NA \\
\hline
\end{tabular}

582 NA, not applicable; NMIBC, non-muscle-invasive bladder cancer; NR, not reported; UTI, urinary tract infection.

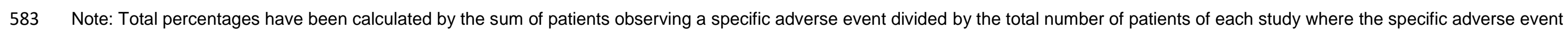
584 is report 
Table 5 | Adverse events in patients with NMIBC treated with conductive hyperthermia using Unithermia.

\begin{tabular}{|c|c|c|c|c|c|c|c|c|c|c|c|c|c|c|}
\hline First author & $\begin{array}{c}\text { Number of } \\
\text { patients }\end{array}$ & $\begin{array}{c}\text { Complete } \\
\text { treatment } \\
(\%)\end{array}$ & $\begin{array}{c}\text { Grade } \geq 3 \\
A E \\
(\%)\end{array}$ & $\begin{array}{l}\text { Haematuria } \\
\text { (\%) }\end{array}$ & $\begin{array}{l}\text { UTI or } \\
\text { sepsis } \\
\text { (\%) }\end{array}$ & $\begin{array}{l}\text { Suprapubic } \\
\text { pain } \\
(\%)\end{array}$ & $\begin{array}{l}\text { Non- } \\
\text { infective } \\
\text { cystitis } \\
(\%)\end{array}$ & $\begin{array}{l}\text { Bladder } \\
\text { spasm or } \\
\text { urgency } \\
(\%)\end{array}$ & $\begin{array}{l}\text { Stricture } \\
(\%)\end{array}$ & $\begin{array}{l}\text { Allergic } \\
\text { reaction } \\
\text { (\%) }\end{array}$ & $\begin{array}{l}\text { Incontinence } \\
(\%)\end{array}$ & $\begin{array}{l}\text { Frequency } \\
\text { (\%) }\end{array}$ & $\begin{array}{c}\text { Bladder } \\
\text { perforation } \\
(\%)\end{array}$ & Refs \\
\hline $\begin{array}{l}\text { Soria et al., } \\
2016\end{array}$ & 34 & 88 & 12 & NR & 4 & $\mathrm{NR}$ & NR & 24 & NR & 6 & 3 & 15 & 0 & 76 \\
\hline $\begin{array}{l}\text { Ekin et al., } \\
2015\end{array}$ & 43 & 93 & 12 & 9 & 0 & 23 & 37 & 21 & 0 & 7 & 2 & 26 & 2 & 33 \\
\hline $\begin{array}{l}\text { Ekin et al., } \\
2015\end{array}$ & 40 & 95 & $\mathrm{NR}$ & $\mathrm{NR}$ & $\mathrm{NR}$ & $\mathrm{NR}$ & $\mathrm{NR}$ & NR & NR & $\mathrm{NR}$ & $\mathrm{NR}$ & NR & $\mathrm{NR}$ & 83 \\
\hline Total & 117 & 94.0 & 11.7 & 9.3 & 3.9 & 23.3 & 37.2 & 22.1 & 0 & 6.5 & 2.6 & 20.8 & 1.3 & NA \\
\hline
\end{tabular}

9.3

23.3

37.2

22.1

0

Note: Total percentages have been calculated by the sum of patients observing a specific adverse event divided by the total number of patients of each study where the specific adverse event is report 
Table 6: Outcomes using EMDA MMC as monotherapy or in combination with BCG for the treatment of NMIBC

\begin{tabular}{|c|c|c|c|c|c|c|c|c|c|c|}
\hline Setting & Patient entry & Number of patients & Risk group & $\begin{array}{l}\text { Carcinoma } \\
\text { in situ }\end{array}$ & $\begin{array}{l}\text { Median follow } \\
\text { up, months (IQR) }\end{array}$ & $\begin{array}{l}\text { Induction treatment } \\
\text { details }\end{array}$ & Maintenance & $\begin{array}{l}\text { RFS and complete } \\
\text { response rate } \\
\text { (where specified) }\end{array}$ & $\begin{array}{l}\text { Progression-free } \\
\text { survival }\end{array}$ & Refs \\
\hline $\begin{array}{l}\text { Single-arm adjuvant } \\
\text { sequential BCG and } \\
\text { EMDA MMC }\end{array}$ & 2009-2013 & 107 & $\begin{array}{l}\text { New or recurrent } \\
\text { high-risk }\end{array}$ & $32 \%$ & 24 & $\begin{array}{l}\text { BCG weekly for week } 1 \\
\text { and } 2 \text { plus EMDA MMC } \\
\text { (40 mg and } 20 \mathrm{~mA} \text { for } \\
30 \text { mins) for week } 3 \text {. } \\
\text { This was repeated } \\
\text { three times. }\end{array}$ & $\begin{array}{l}3 \text { once weekly BCG } 3 \\
\text { months after } \\
\text { induction and every } 6 \\
\text { months for } 3 \text { years. }\end{array}$ & RFS: $68 \%$ & $3 \%$ & 92 \\
\hline $\begin{array}{l}\text { RCT of TURBT versus } \\
\text { TUBRT plus immediate } \\
\text { postoperative MMC } \\
\text { (adjuvant) versus } \\
\text { neoadjuvant EMDA } \\
\text { MMC plus TURBT }\end{array}$ & 1994- 2003 & $\begin{array}{l}374: \\
124 \text { TURBT } \\
126 \text { TUBRT plus } \\
\text { immediate } \\
\text { postoperative MMC } \\
124 \text { neoadjuvant } \\
\text { EMDA MMC plus } \\
\text { TURBT }\end{array}$ & $\begin{array}{l}\text { Low-risk (6\%), } \\
\text { intermediate-risk } \\
\text { (66\%),or high-risk } \\
\text { (28\%) (no previously } \\
\text { intravesical } \\
\text { treatment) }\end{array}$ & $0 \%$ & 86 (57-125) & $\begin{array}{l}\text { TURBT alone } \\
\text { TURBT plus immediate } \\
\text { postoperative MMC } 40 \\
\text { mg MMC in } 50 \mathrm{ml} \\
\text { water (60 minutes) } \\
\text { Neoadjuvant EMDA } \\
\text { plus TURBT } 40 \mathrm{mg} \\
\text { MMC in } 100 \mathrm{ml} \text { water } \\
\text { (20 mA for } 30 \mathrm{mins} \text { ). }\end{array}$ & $\begin{array}{l}\text { All groups } \\
\text { Intermediate-risk: } 6 \\
\text { once weekly40 mg } \\
\text { MMC in } 50 \mathrm{ml} \text { water } \\
\text { High-risk: } 6 \text { once } \\
\text { weekly } 81 \mathrm{mg} \mathrm{BCG} \\
\text { (ImmuCyst) in } 50 \mathrm{ml} \\
\text { saline for } 120 \mathrm{mins}\end{array}$ & $\begin{array}{l}\text { RFS: TURBT: } 36 \% \text {, } \\
\text { TURBT plus MMC: } \\
\text { 41\%, } \\
\text { Neoadjuvant EMDA } \\
\text { MMC plus TURBT: } \\
62 \% \text { (p } 50.0001 \text { ) }\end{array}$ & $\begin{array}{l}\text { PFS TURBT: } 79 \% \\
\text { TURBT plus MMC: } \\
81 \% \\
\text { Neoadjuvant EMDA } \\
\text { MMC plus TURBT: } \\
94 \%\end{array}$ & 90 \\
\hline $\begin{array}{l}\text { RCT of adjuvant BCG } \\
\text { versus } B C G \text { and EMDA }\end{array}$ & 1994- 2002 & $\begin{array}{l}212: \\
105 \text { BCG } \\
107 \text { BCG and EMDA }\end{array}$ & $\begin{array}{l}\text { High-risk- all pT1 } \\
\text { (previous intravesical } \\
\text { treatment: } 42 \%)\end{array}$ & $27 \%$ & 88 (63-110) & $\begin{array}{l}\text { BCG alone: } 81 \mathrm{mg} \mathrm{BCG} \\
\text { over } 120 \text { mins weekly } \\
\text { for } 6 \text { once weeks } \\
\text { BCG and EMDA: } 81 \mathrm{mg} \\
\text { BCG over } 120 \text { mins } \\
\text { weekly for } 2 \text { weeks } \\
\text { then } 40 \mathrm{mg} \text { EMDA (20 } \\
\text { mA for } 30 \text { mins) } \\
\text { weekly repeated } 3 \\
\text { times ( } 9 \text { instillations in } \\
\text { total) plus } \\
\text { maintenance }\end{array}$ & $\begin{array}{l}\text { BCG alone: once } \\
\text { monthly for } 10 \\
\text { months } \\
\text { BCG and EMDA: } 40 \mathrm{mg} \\
\text { EMDA monthly for } 2 \\
\text { months then } 81 \mathrm{mg} \\
\text { BCG for month } 3 . \\
\text { Repeated for three } \\
\text { cycles }\end{array}$ & $\begin{array}{l}\text { RFS: } \\
\text { BCG alone: } 42.1 \% \text {, } \\
\text { BCG plus EMDA: } \\
58.1 \%(\mathrm{p}=0.0012)\end{array}$ & $\begin{array}{l}\text { PFS: BCG alone: } \\
\text { 78.1\%, } \\
\text { BCG and EMDA: } \\
90.7 \% \text { (p=0.004) } \\
\\
\text { OS: BCG alone: } \\
67.6 \% \text {, BCG and } \\
\text { EMDA: } 78.5 \% \\
\text { (p=0.045) } \\
\text { CSS: BCG alone: } \\
\text { 89.4\%, BCG and } \\
\text { EMDA: } 94.4 \% \\
(p=0.01)\end{array}$ & 93 \\
\hline
\end{tabular}




\begin{tabular}{|c|c|c|c|c|c|c|c|c|c|c|}
\hline $\begin{array}{l}\text { RCT of adjuvant EMDA } \\
\text { MMC versus } M M C \\
\text { alone versus } B C G\end{array}$ & 1994- 2001 & $\begin{array}{l}108: \\
\text { 36 EMDA MMC } \\
36 \mathrm{MMC} \\
36 \mathrm{BCG}\end{array}$ & $\begin{array}{l}\text { High-risk CIS } \pm \text { pT1 } \\
\text { (previous intravesical } \\
\text { treatment not } \\
\text { specified) }\end{array}$ & $100 \%$ & $6(6)$ & $\begin{array}{l}\text { All: } 6 \text { once weekly: } \\
\text { EMDA MMC } 40 \mathrm{mg} \\
(20 \mathrm{~mA}) \text { in } 100 \mathrm{ml} \\
\text { water for } 30 \mathrm{mins} \\
\\
\text { MMC: } 40 \mathrm{mg} \text { in } 100 \mathrm{ml} \\
\text { water for } 60 \mathrm{mins} \\
\text { BCG: } 81 \mathrm{mg} \text { in } 50 \mathrm{ml} \\
\text { saline for } 120 \mathrm{mins} \text {. }\end{array}$ & $\begin{array}{l}\text { All: } 10 \text { monthly } \\
\text { instillations if } \\
\text { response } \\
\text { Non-responders at } 3 \\
\text { months re-challenged } \\
\text { with another } 6 \text { weeks } \\
\text { induction. }\end{array}$ & $\begin{array}{l}\text { Time to recurrence: } \\
\text { EMDA MMC: } \\
6 \text { month, } \\
\text { MMC alone: } 20 \\
\text { months, BCG: } 26 \\
\text { months, }(\mathrm{p}=0.013) \\
\\
\text { CR: EMDA MMC: } \\
58 \%, \text { MMC alone: } \\
31 \%, B C G: \\
64 \%(p=0.012)\end{array}$ & $\begin{array}{l}\text { No difference in } \\
\text { progression }\end{array}$ & 94 \\
\hline $\begin{array}{l}\text { Ablative non- } \\
\text { randomized } \\
\text { comparative study of } \\
\text { RITE, MMC, and EMDA } \\
\text { MMC }\end{array}$ & 1996-1998 & $\begin{array}{l}80: \\
29 \mathrm{RITE} \\
36 \mathrm{MMC} \\
15 \mathrm{EMDA}\end{array}$ & Low-risk & NA & $\begin{array}{l}\text { 7-10 days after } \\
\text { treatment }\end{array}$ & $\begin{array}{l}\text { All: } 4 \text { once weekly: } \\
\text { MMC } 40 \mathrm{mg} \text { in } 50 \mathrm{ml} \\
\text { saline for } 60 \mathrm{mins} \\
\text { RITE: } 40 \mathrm{mg} \mathrm{MMC} \text { in } \\
50 \mathrm{ml} \text { water (42.5C) } \\
\text { for } 60 \mathrm{mins} \\
\text { EMDA MMC: } 40 \mathrm{mg} \\
\text { MMC ( } 20 \mathrm{~mA} \text { ) in } 150 \\
\mathrm{ml} \text { water for } 20 \mathrm{mins}\end{array}$ & NA & $\begin{array}{l}\text { CR } \\
\text { MMC: } 27.7 \% \\
\text { RITE: } 66 \%, \\
\text { EMDA: } 40 \%\end{array}$ & NA & 48 \\
\hline $\begin{array}{l}\text { Single-arm adjuvant } \\
\text { EMDA MMC }\end{array}$ & $\mathrm{NA}$ & 22 EMDA MMC & $\begin{array}{l}\text { Low-risk (5\%), } \\
\text { intermediate-risk } \\
\text { (67\%), or high-risk } \\
\text { (28\%) (previous } \\
\text { intravesical treatment } \\
\text { not specified) }\end{array}$ & $9 \%$ & 14.1 & $\begin{array}{l}4 \text { once weekly EMDA } \\
\text { MMC } 40 \mathrm{mg} \text { in } 100 \mathrm{ml} \\
\text { saline }(15 \mathrm{~mA}) \text { for } 20 \\
\text { mins }\end{array}$ & NA & RFS: $56.3 \%$ & $\mathrm{NA}$ & 95 \\
\hline $\begin{array}{l}\text { Non-randomized } \\
\text { comparison study of } \\
\text { adjuvant EMDA MMC } \\
\text { versus MMC }\end{array}$ & 1993-1995 & $\begin{array}{l}28: \\
13 \text { MMC } \\
15 \text { EMDA MMC }\end{array}$ & $\begin{array}{l}\text { Low-risk (36\%), } \\
\text { intermediate-risk } \\
(14 \%) \text { and high-risk } \\
\text { (50\%) (previous } \\
\text { intravesical treatment } \\
\text { not specified) }\end{array}$ & $0 \%$ & $\begin{array}{c}\text { MMC: } 10.5 \\
\text { EDMA MMC: } \\
14.5\end{array}$ & $\begin{array}{l}\text { MMC: } 8 \text { once weekly } \\
40 \mathrm{mg} 50 \mathrm{ml} \text { water for } \\
120 \mathrm{mins} \\
\text { EMDA MMC: } 8 \text { once } \\
\text { weekly } 40 \mathrm{mg} \text { MMC } \\
(15 \mathrm{~mA}) \text { for } 20 \mathrm{mins}\end{array}$ & NA & $\begin{array}{l}\text { CR: MMC: } \\
41.6 \% \text {, EMDA MMC: } \\
40 \% \\
\text { RFS: MMC: } 15.4 \% \text {, } \\
\text { EMDA MMC: } \\
26.7\end{array}$ & NA & 91 \\
\hline
\end{tabular}

CR, complete response; DFS, disease-free survival; EMDA, electromotive drug administration; MMC, mitomycin C; NA, not applicable; NMIBC, non-muscle-invasive bladder cancer; RCT, randomized control trial; RITE, radiofrequency induced thermochemotherapeutic effect; RFS, recurrence-free survival; TURBT, transurethral resection of

bladder tumour. 


\begin{tabular}{|c|c|c|c|c|c|c|c|c|c|c|}
\hline First author & $\begin{array}{c}\text { Number of } \\
\text { patients }\end{array}$ & $\begin{array}{l}\text { Complete treatment } \\
\text { (\%) }\end{array}$ & $\begin{array}{c}\text { Grade } \geq 3 \\
\text { adverse events } \\
\text { (\%) }\end{array}$ & Haematuria (\%) & $\begin{array}{l}\text { UTI or sepsis } \\
\text { (\%) }\end{array}$ & Suprapubic pain (\%) & $\begin{array}{l}\text { Non-infective } \\
\text { cystitis (\%) }\end{array}$ & $\begin{array}{c}\text { Bladder spasm or } \\
\text { urgency(\%) }\end{array}$ & $\begin{array}{l}\text { Allergic reaction } \\
(\%)\end{array}$ & Refs \\
\hline Di Stasi et al., 2003 & 36 & 92 & 8 & 8 & 19 & 0 & 36 & 0 & 8 & 94 \\
\hline Riedi et al., 1998 & 22 & 86 & NR & 5 & 5 & 18 & 9 & 63 & 0 & 95 \\
\hline Brausi et al., 1998 & 15 & 93 & NR & 0 & 0 & 0 & 13 & 0 & 13 & 91 \\
\hline Total & 73 & 90.4\% & $8.3 \%$ & $12.7 \%$ & $11.0 \%$ & $5.5 \%$ & $23.3 \%$ & $19.2 \%$ & $5.5 \%$ & NA \\
\hline
\end{tabular}

EMDA, electromotive drug administration; MMC, mitomycin C; NA, not applicable; NMIBC, non-muscle-invasive bladder cancer; NR, not reported; UTI, urinary tract infection.

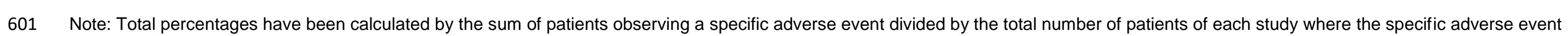


Table 8: Estimated end-user cost of intravesical device-assisted therapies for bladder cancer

\begin{tabular}{|c|c|c|c|c|}
\hline Factor & Synergo & HIVEC & Unithermia & EMDA \\
\hline $\begin{array}{l}\text { Estimated end-user cost }(£) \text { of disposables } \\
\text { per treatment }\end{array}$ & 650 & 195 & 150 & 260 \\
\hline Number of treatments & $\begin{array}{l}6 \text { once weeklyinduction plus } \\
\text { maintenance of } 1 \text { treatment every } 6 \\
\text { weeks for year one ( } 6 \text { treatments) and } \\
1 \text { treatment every } 8 \text { weeks for year } \\
\text { two ( } 7 \text { treatments) }=19 \text { treatments } \\
\text { total }\left.\right|^{47} \\
6 \text { weekly induction plus } 3 \text { weekly at } 3 \text {, } \\
6 \text {, and } 12 \text { months, } 15 \text { treatments } \\
\text { total }^{31}\end{array}$ & $\begin{array}{l}6 \text { weekly plus } 6 \text { monthly treatments, } 12 \\
\text { treatments total }{ }^{32} \\
6 \text { weekly plus } 9 \text { monthly treatments, } 15 \\
\text { treatments total }\end{array}$ & $\begin{array}{l}6 \text { weekly plus } 3 \text { weekly } \\
\text { instillations at } 3 \text { and } 6 \text { months, } \\
12 \text { treatments total }\left.\right|^{33,83}\end{array}$ & $\begin{array}{l}\text { BCG and EMDA: } 9 \text { weekly treatments } \\
\text { ( } 2 \text { BCG treatments plus } 1 \text { EMDA } \\
\text { treatments repeated } 3 \text { times) plus } 9 \\
\text { monthly }(2 \times \text { EMDA plus } 1 \text { X BCG } \\
\text { repeated } 3 \text { times), } 9 \text { EMDA plus } 9 \text { BCG } \\
\text { total }^{93} \\
\text { EMDA: } 6 \text { weekly plus } 10 \text { monthly } \\
\text { EMDA, } 16 \text { treatments total }{ }^{94}\end{array}$ \\
\hline Time for each treatment session (min) & 30 plus 30 & 60 & 50 & 30 \\
\hline $\begin{array}{l}\text { Estimated end-user cost of disposables for } 6 \\
\text { weekly induction treatment }\end{array}$ & 3,900 & 1,170 & 900 & $\begin{array}{l}\text { BCG and EMDA: } 780 \\
\text { EMDA: } 1,560\end{array}$ \\
\hline Total cost of MMC for induction ( $\left.£ 80 / u^{\prime} i t\right)^{\ddagger}$ & 480 & 480 & 480 & $\begin{array}{l}\text { BCG and EMDA: } 240 \\
\text { EMDA: } 480\end{array}$ \\
\hline Total cost of BCG for induction ( $€ 120 / \mathrm{unit}^{\ddagger}{ }^{\ddagger}$ & NA & NA & NA & BCG and EMDA: 720 \\
\hline $\begin{array}{l}\text { Estimated total end-user cost for } 6 \text { weekly } \\
\text { induction treatment }\end{array}$ & 4,380 & 1,650 & 1,380 & $\begin{array}{l}\text { BCG and EMDA: } 1,740 \\
\text { EMDA: } 2,040\end{array}$ \\
\hline $\begin{array}{l}\text { Estimated end-user cost of disposables for } \\
\text { induction and maintenance treatment }\end{array}$ & $9,750-12,350$ & $2,340-2,925$ & 1,800 & $\begin{array}{l}\text { BCG and EMDA: } 2,340 \\
\text { EMDA: } 4,160\end{array}$ \\
\hline $\begin{array}{l}\text { Total cost of MMC for induction and } \\
\text { maintenance ( }(80 / \text { unit) }\end{array}$ & $1,200-1,520$ & $960-1,200$ & 960 & $\begin{array}{l}\text { BCG and EMDA: } 720 \\
\text { EMDA: } 1,280\end{array}$ \\
\hline $\begin{array}{l}\text { Total cost of BCG for induction and } \\
\text { maintenance ( } f 120 / \text { unit) })^{\ddagger}\end{array}$ & NA & NA & NA & BCG and EMDA: 1,080 \\
\hline $\begin{array}{l}\text { Estimated end-user cost for induction and } \\
\text { maintenance treatment }\end{array}$ & $10,950-13,870$ & $3,300-4,125$ & 2,760 & $\begin{array}{l}\text { BCG and EMDA: } 4,140 \\
\text { EMDA: } 5,440\end{array}$ \\
\hline
\end{tabular}

$607{ }^{\ddagger}$ Prices according to the British National Formulary

608 EMDA, electromotive drug administration; MMC, mitomycin C; NA, not applicable. 


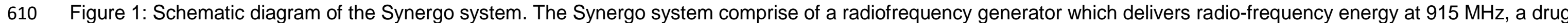

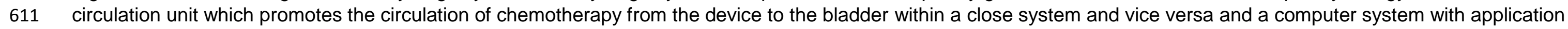

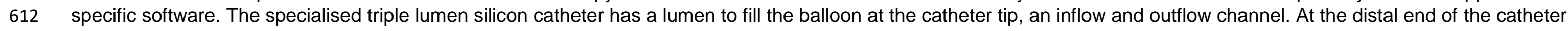

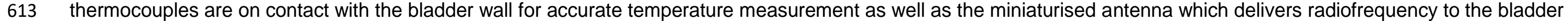
614 wall. Reproduced with permission
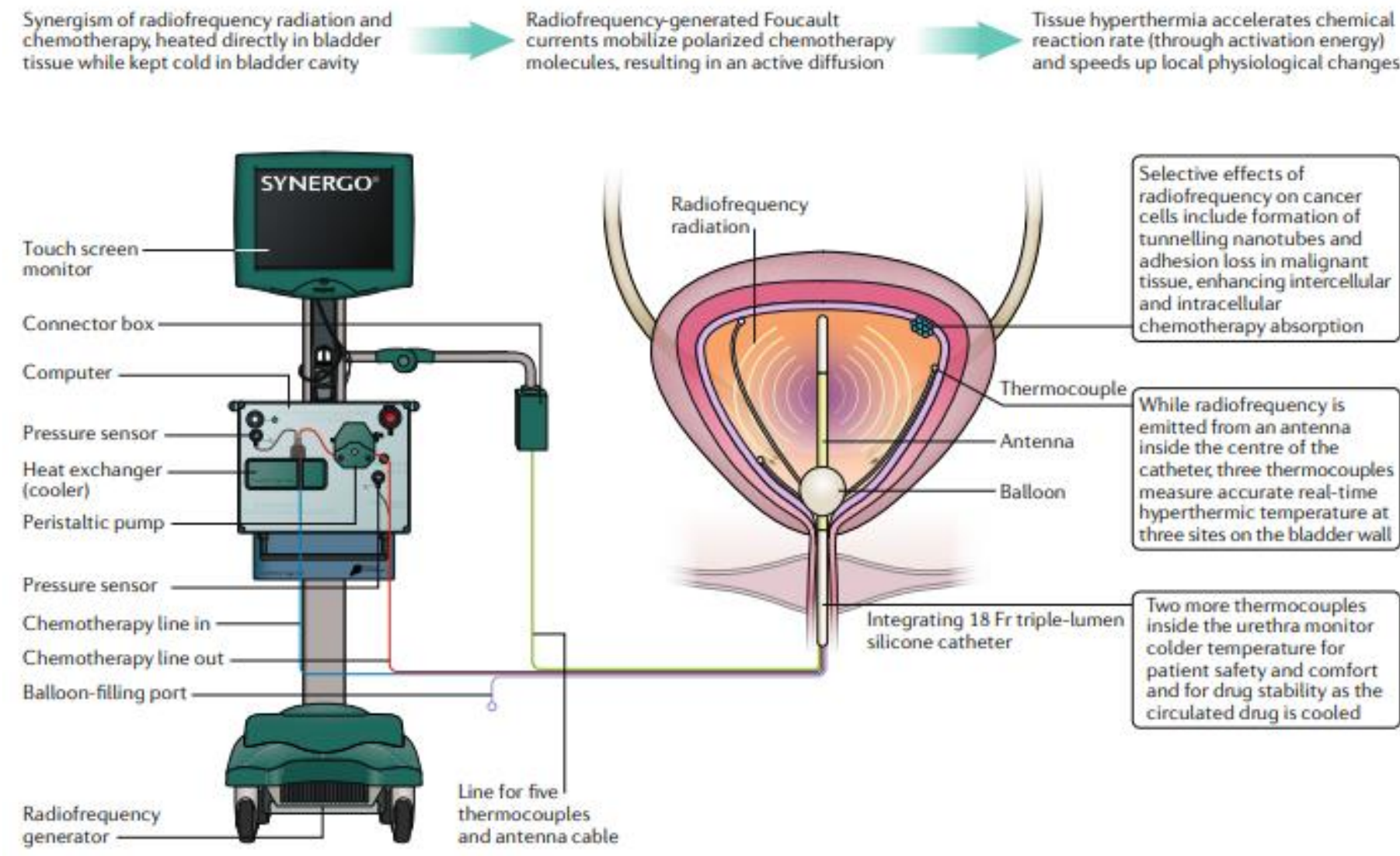
616 Figure 2: Schematic diagram of the Combat BRS system. The Combat BRS system uses an aluminium heat exchange to allow efficient heat transfer. Circulating

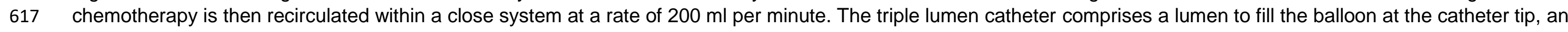

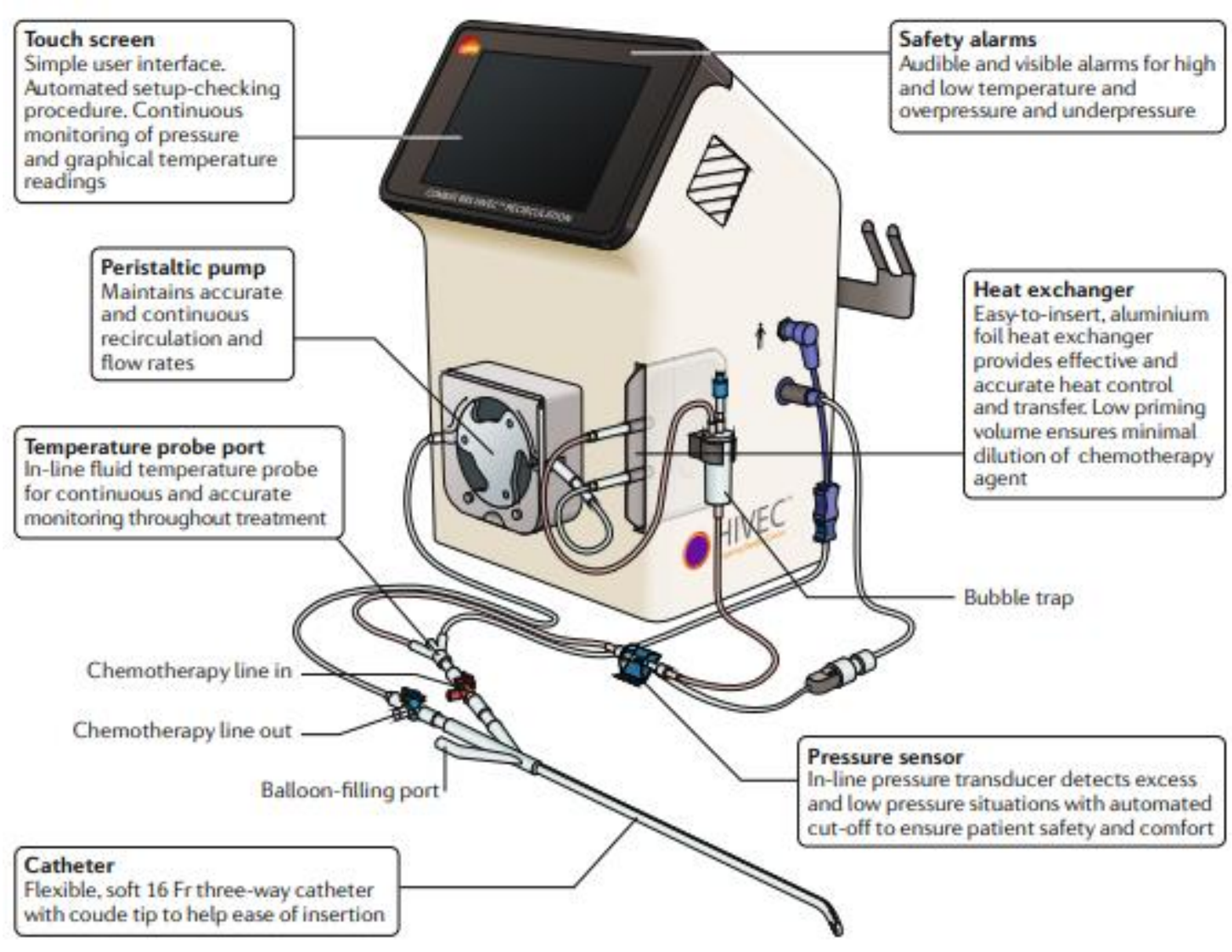




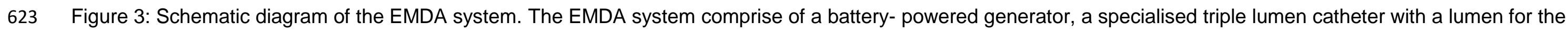

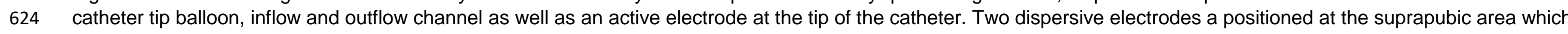
625 acts as dispersive ground electrodes. Reproduced with permission
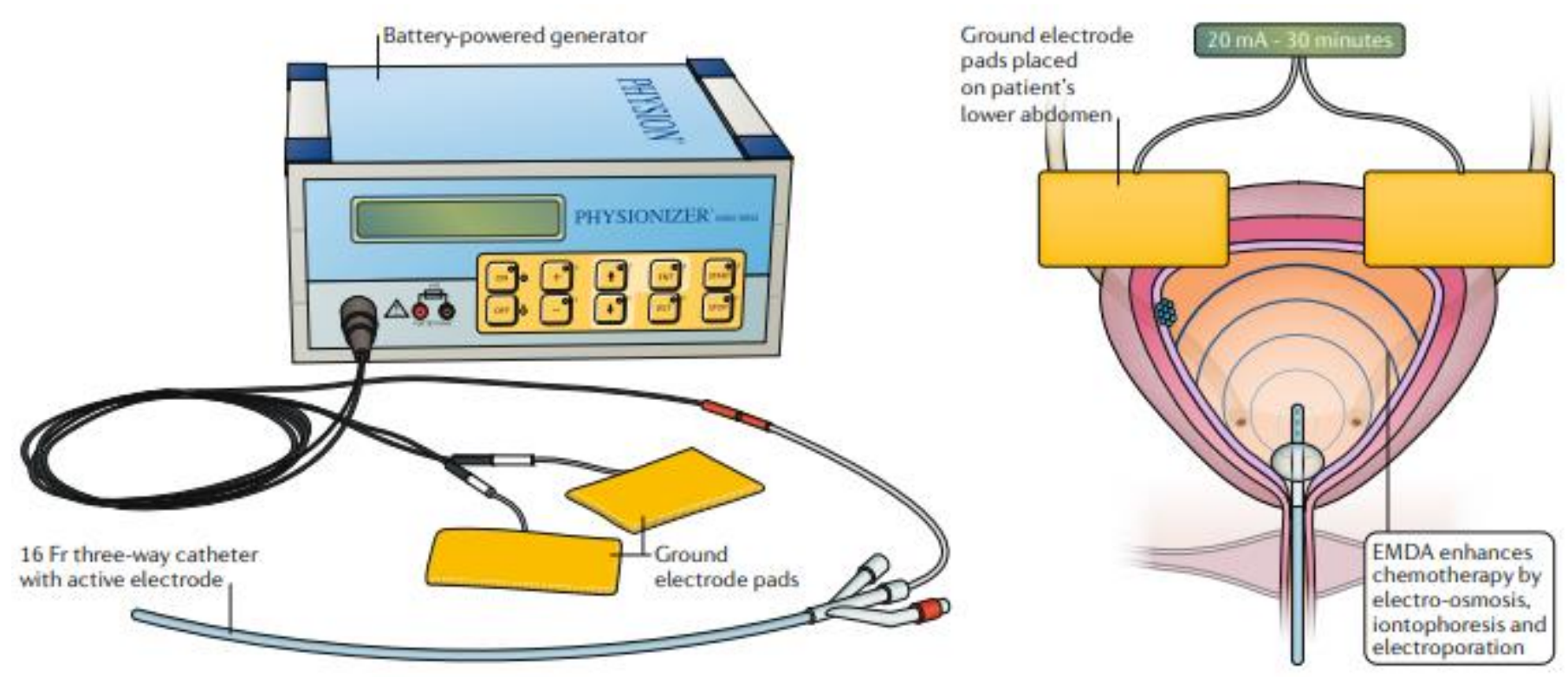


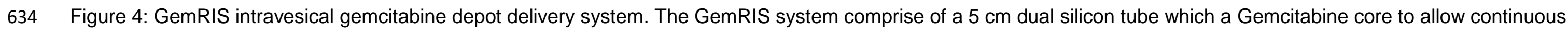

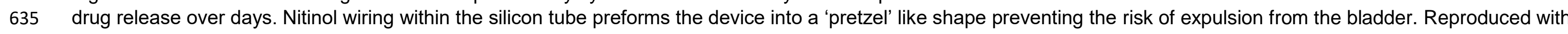
636 permission

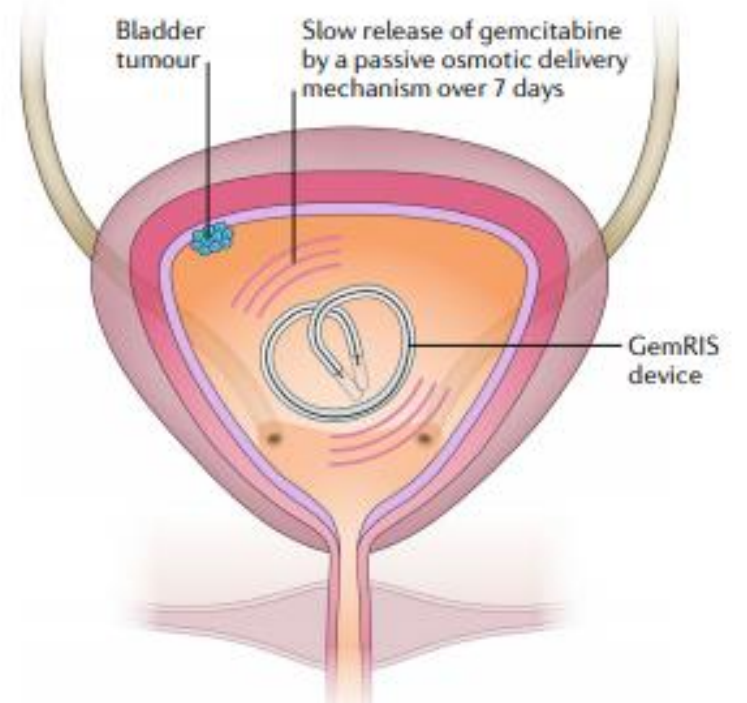

637 
645 Supplementary Table 3: Comparison of reported adverse events in RCTs between RITE, BCG and MMC alone

\begin{tabular}{|c|c|c|c|}
\hline BCG & RITE & MMC alone & Refs \\
\hline NA & $\begin{array}{l}\text { Increased pain, } \\
\text { bladder wall } \\
\text { erythema } \\
\text { No difference in } \\
\text { dysuria, haematuria, } \\
\text { urethral stenosis, or } \\
\text { allergy }\end{array}$ & $\begin{array}{l}\text { No difference in } \\
\text { dysuria, } \\
\text { haematuria, } \\
\text { urethral stenosis, } \\
\text { allergy }\end{array}$ & 60 \\
\hline $\begin{array}{l}\text { Increased urinary } \\
\text { frequency, nocturia, } \\
\text { incontinence, } \\
\text { haematuria, fever, } \\
\text { fatigue, arthralgia, } \\
\text { and cystitis } \\
\text { No difference in } \\
\text { urinary tract } \\
\text { infection or residual } \\
\text { urine volume }\end{array}$ & $\begin{array}{l}\text { Increased bladder } \\
\text { pain, bladder spasm, } \\
\text { catheterisation } \\
\text { difficulty, urethral } \\
\text { stricture, bladder } \\
\text { wall erythema, and } \\
\text { allergic reaction } \\
\text { No difference in } \\
\text { urinary tract } \\
\text { infection or residual } \\
\text { urine volume }\end{array}$ & NA & 53 \\
\hline
\end{tabular}

646 MMC, mitomycin C; RCT, randomized control trial; RITE, radiofrequency-induced thermochemotherapeutic effect. 
Ferlay, J. et al. Cancer incidence and mortality worldwide: sources, methods and major patterns in GLOBOCAN 2012. Int J Cancer 136, 9 (2015).

2 Tan, W. S., Rodney, S., Lamb, B., Feneley, M. \& Kelly, J. Management of non-muscle invasive bladder cancer: A comprehensive analysis of guidelines from the United States, Europe and Asia. Cancer treatment reviews 47, 22-31 (2016).

3 Colombo, R. et al. Thermo-chemotherapy and electromotive drug administration of mitomycin $\mathrm{C}$ in superficial bladder cancer eradication. a pilot study on marker lesion. Eur Urol 39, 95-100 (2001).

4 Di Stasi, S. M. et al. Electromotive instillation of mitomycin immediately before transurethral resection for patients with primary urothelial non-muscle invasive bladder cancer: a randomised controlled trial. Lancet Oncol 12, 871-879 (2011).

5 Sylvester, R. J. et al. Systematic Review and Individual Patient Data Meta-analysis of Randomized Trials Comparing a Single Immediate Instillation of Chemotherapy After Transurethral Resection with Transurethral Resection Alone in Patients with Stage pTa-pT1 Urothelial Carcinoma of the Bladder: Which Patients Benefit from the Instillation? Eur Urol 69, 231-244, doi:10.1016/j.eururo.2015.05.050 (2016).

6 Huncharek, M., Geschwind, J. F., Witherspoon, B., McGarry, R. \& Adcock, D. Intravesical chemotherapy prophylaxis in primary superficial bladder cancer: a meta-analysis of 3703 patients from 11 randomized trials. J Clin Epidemiol 53, 676-680 (2000).

7 Shariat, S. F., Chade, D. C., Karakiewicz, P. I., Scherr, D. S. \& Dalbagni, G. Update on intravesical agents for non-muscle-invasive bladder cancer. Immunotherapy 2, 381-392, doi:10.2217/imt.10.1 (2010).

8 Tomasz, M. Mitomycin C: small, fast and deadly (but very selective). Chem Biol 2, 575-579 (1995).

9 Bohle, A., Jocham, D. \& Bock, P. R. Intravesical bacillus Calmette-Guerin versus mitomycin C for superficial bladder cancer: a formal meta-analysis of comparative studies on recurrence and toxicity. J Urol 169, 90-95 (2003).

10 Sylvester, R. J., Oosterlinck, W. \& van der Meijden, A. P. A single immediate postoperative instillation of chemotherapy decreases the risk of recurrence in patients with stage Ta T1 bladder cancer: a meta-analysis of published results of randomized clinical trials. J Urol 171, 2186-2190 (2004).

11 Addeo, R. et al. Randomized phase III trial on gemcitabine versus mytomicin in recurrent superficial bladder cancer: evaluation of efficacy and tolerance. J Clin Oncol 28, 543-548, doi:10.1200/jco.2008.20.8199 (2010).

12 Messing, E. M. et al. Effect of Intravesical Instillation of Gemcitabine vs Saline Immediately Following Resection of Suspected Low-Grade Non-Muscle-Invasive Bladder Cancer on Tumor Recurrence: SWOG S0337 Randomized Clinical Trial. Jama 319, 1880-1888, doi:10.1001/jama.2018.4657 (2018).

13 Lamm, D. L. et al. Maintenance bacillus Calmette-Guerin immunotherapy for recurrent TA, $\mathrm{T} 1$ and carcinoma in situ transitional cell carcinoma of the bladder: a randomized Southwest Oncology Group Study. J Urol 163, 1124-1129 (2000).

14 Ojea, A. et al. A multicentre, randomised prospective trial comparing three intravesical adjuvant therapies for intermediate-risk superficial bladder cancer: low-dose bacillus Calmette-Guerin (27 mg) versus very low-dose bacillus Calmette-Guerin (13.5 mg) versus mitomycin C. Eur Urol 52, 1398-1406 (2007).

15 Loftus, P. in The Wall Street Journal (2016).

16 Cambier, S. et al. EORTC Nomograms and Risk Groups for Predicting Recurrence, Progression, and Disease-specific and Overall Survival in Non-Muscle-invasive Stage Ta-T1 Urothelial Bladder Cancer Patients Treated with 1-3 Years of Maintenance Bacillus CalmetteGuerin. Eur Urol 69, 60-69 (2016).

17 Spiess, P. E. et al. Bladder Cancer, Version 5.2017, NCCN Clinical Practice Guidelines in Oncology. Journal of the National Comprehensive Cancer Network 15, 1240-1267 (2017).

18 Daneshmand, S., Pohar, K. S., Steinberg, G. D., Aron, M. \& Cutie, C. Effect of GemRIS (gemcitabine-releasing intravesical system, TAR-200) on antitumor activity in muscleinvasive bladder cancer (MIBC). J. Clin. Oncol. 35, e16000-e16000, doi:10.1200/JCO.2017.35.15_suppl.e16000 (2017).

19 Lenis, A. et al. PD19-10 THE CHEMOABLATIVE EFFECT OF VESIGEL INSTILLATION IN PATIENTS WITH NMIBC - RESPONSE RATE AND 1-YEAR DURABILITY. The Journal of Urology 197, e368e369, doi:10.1016/j.juro.2017.02.883. 
20 Schaaf, L. et al. Hyperthermia Synergizes with Chemotherapy by Inhibiting PARP1Dependent DNA Replication Arrest. Cancer Res 76, 2868-2875, doi:10.1158/0008-5472.can15-2908 (2016).

21 Westra, A. \& Dewey, W. C. Variation in sensitivity to heat shock during the cell-cycle of Chinese hamster cells in vitro. Int J Radiat Biol Relat Stud Phys Chem Med 19, 467-477 (1971).

22 Mantso, T. et al. Effects of hyperthermia as a mitigation strategy in DNA damage-based cancer therapies. Seminars in cancer biology 37-38, 96-105, doi:10.1016/j.semcancer.2016.03.004 (2016).

23 Mallory, M., Gogineni, E., Jones, G. C., Greer, L. \& Simone, C. B., 2nd. Therapeutic hyperthermia: The old, the new, and the upcoming. Critical reviews in oncology/hematology 97, 56-64, doi:10.1016/j.critrevonc.2015.08.003 (2016).

24 Lefor, A. T., Makohon, S. \& Ackerman, N. B. The effects of hyperthermia on vascular permeability in experimental liver metastasis. J. Surg. Oncol. 28, 297-300 (1985).

25 Song, C. W. Effect of hyperthermia on vascular functions of normal tissues and experimental tumors; brief communication. J. Natl. Cancer Inst. 60, 711-713 (1978).

26 Kampinga, H. H. Cell biological effects of hyperthermia alone or combined with radiation or drugs: a short introduction to newcomers in the field. Int. J. Hyperthermia 22, 191-196, doi:10.1080/02656730500532028 (2006).

27 Milani, V. et al. Heat shock protein 70: role in antigen presentation and immune stimulation. Int. J. Hyperthermia 18, 563-575, doi:10.1080/02656730210166140 (2002).

28 Cavaliere, R. et al. Selective heat sensitivity of cancer cells. Biochemical and clinical studies. Cancer 20, 1351-1381 (1967).

29 Matzkin, H., Rangel, M. C. \& Soloway, M. S. In vitro study of the effect of hyperthermia on normal bladder cell line and on five different transitional cell carcinoma cell lines. $J$ Urol 147, 1671-1674 (1992).

30 van der Heijden, A. G., Verhaegh, G., Jansen, C. F., Schalken, J. A. \& Witjes, J. A. Effect of hyperthermia on the cytotoxicity of 4 chemotherapeutic agents currently used for the treatment of transitional cell carcinoma of the bladder: an in vitro study. J Urol 173, 13751380 (2005).

31 Arends, T. J. et al. Results of a Randomised Controlled Trial Comparing Intravesical Chemohyperthermia with Mitomycin C Versus Bacillus Calmette-Guerin for Adjuvant Treatment of Patients with Intermediate- and High-risk Non-Muscle-invasive Bladder Cancer. Eur. Urol. 69, 1046-1052, doi:10.1016/j.eururo.2016.01.006 (2016).

32 Sousa, A. et al. Recirculant hyperthermic IntraVEsical chemotherapy (HIVEC) in intermediatehigh-risk non-muscle-invasive bladder cancer. Int. J. Hyperthermia 32, 374-380 (2016).

33 Ekin, R. G. et al. Results of Intravesical Chemo-Hyperthermia in High-risk Non-muscle Invasive Bladder Cancer. Asian Pac. J. Cancer Prev. 16, 3241-3245 (2015).

34 Longo, T. A. et al. A systematic review of regional hyperthermia therapy in bladder cancer. Int. J. Hyperthermia 32, 381-389 (2016).

35 Garden, O. J. et al. Guidelines for resection of colorectal cancer liver metastases. Gut 55 Suppl 3, iii1-8, doi:10.1136/gut.2006.098053 (2006).

36 Shaheen, N. J. et al. Radiofrequency ablation in Barrett's esophagus with dysplasia. N Engl J Med 360, 2277-2288, doi:10.1056/NEJMoa0808145 (2009).

37 Vargas, H. I. et al. Focused microwave phased array thermotherapy for ablation of earlystage breast cancer: results of thermal dose escalation. Ann. Surg. Oncol. 11, 139-146 (2004). 38 Okuma, T. et al. Assessment of early treatment response after CT-guided radiofrequency ablation of unresectable lung tumours by diffusion-weighted MRI: a pilot study. Br. J. Radiol. 82, 989-994, doi:10.1259/bjr/13217618 (2009).

39 Erce, C. \& Parks, R. W. Interstitial ablative techniques for hepatic tumours. The British journal of surgery 90, 272-289, doi:10.1002/bjs.4091 (2003).

40 Brace, C. L. Radiofrequency and microwave ablation of the liver, lung, kidney, and bone: what are the differences? Current problems in diagnostic radiology 38, 135-143, doi:10.1067/j.cpradiol.2007.10.001 (2009).

41 van Valenberg, F. J. P. et al. Intravesical radiofrequency induced hyperthermia enhances mitomycin C accumulation in tumour tissue. Int J Hyperthermia 1, 1-6 (2017).

42 Paroni, R. et al. Effect of local hyperthermia of the bladder on mitomycin C pharmacokinetics during intravesical chemotherapy for the treatment of superficial transitional cell carcinoma. Br J Clin Pharmacol 52, 273-278 (2001).

43 Ware, M. J. et al. Radiofrequency treatment alters cancer cell phenotype. Scientific reports 5, 12083, doi:10.1038/srep12083 (2015). 
Colombo, R. et al. A new approach using local combined microwave hyperthermia and chemotherapy in superficial transitional bladder carcinoma treatment. J Urol 153, 959-963 (1995).

45 Dalton, J. T., Wientjes, M. G., Badalament, R. A., Drago, J. R. \& Au, J. L. Pharmacokinetics of intravesical mitomycin $C$ in superficial bladder cancer patients. Cancer Res. 51, 5144-5152 (1991).

46 Alfred Witjes, J., Hendricksen, K., Gofrit, O., Risi, O. \& Nativ, O. Intravesical hyperthermia and mitomycin-C for carcinoma in situ of the urinary bladder: experience of the European Synergo ${ }^{\circledR}$ working party. World journal of urology 27, 319-324, doi:10.1007/s00345-0090384-2 (2009).

47 Tan, W. S. et al. Radiofrequency-induced thermo-chemotherapy effect plus mitomycin versus a second course of bacillus Calmette-Gu\&\#xe9;rin (BCG) or institutional standard in patients with recurrence of non-muscle invasive bladder cancer following induction or maintenance BCG therapy (HYMN): A phase III, open-label, randomised controlled trial. Eur Urol Supp 16, e1156-e1157, doi:10.1016/s1569-9056(17)30720-0 (2017).

48 Colombo, R. et al. Thermo-chemotherapy and electromotive drug administration of mitomycin $\mathrm{C}$ in superficial bladder cancer eradication. a pilot study on marker lesion. Eur. Urol. 39, 95-100 (2001).

49 Colombo, R. et al. Local microwave hyperthermia and intravesical chemotherapy as bladder sparing treatment for select multifocal and unresectable superficial bladder tumors. J Urol 159, 783-787 (1998).

50 Colombo, R. et al. Neoadjuvant combined microwave induced local hyperthermia and topical chemotherapy versus chemotherapy alone for superficial bladder cancer. J Urol 155, 1227 1232 (1996).

51 Rigatti, P., Lev, A. \& Colombo, R. Combined intravesical chemotherapy with mitomycin C and local bladder microwave-induced hyperthermia as a preoperative therapy for superficial bladder tumors. A preliminary clinical study. Eur. Urol. 20, 204-210 (1991).

52 Sooriakumaran, P. et al. Predictive Factors for Time to Progression after Hyperthermic Mitomycin C Treatment for High-Risk Non-Muscle Invasive Urothelial Carcinoma of the Bladder: An Observational Cohort Study of 97 Patients. Urol Int 96, 83-90 (2016).

53 Arends, T. J. et al. Results of a Randomised Controlled Trial Comparing Intravesical Chemohyperthermia with Mitomycin C Versus Bacillus Calmette-Guerin for Adjuvant Treatment of Patients with Intermediate- and High-risk Non-Muscle-invasive Bladder Cancer. Eur. Urol. 20, 00057-00059 (2016).

54 Erturhan, S. et al. Thermochemotherapy in adjuvant treatment of primary high risk non muscle invasive bladder cancers: Single center results. Arch. Esp. Urol. 68, 666-671 (2015).

55 Maffezzini, M. et al. Intravesical mitomycin C combined with local microwave hyperthermia in non-muscle-invasive bladder cancer with increased European Organization for Research and Treatment of Cancer (EORTC) score risk of recurrence and progression. Cancer Chemother. Pharmacol. 73, 925-930 (2014).

56 Colombo, R., Salonia, A., Leib, Z., Pavone-Macaluso, M. \& Engelstein, D. Long-term outcomes of a randomized controlled trial comparing thermochemotherapy with mitomycin-C alone as adjuvant treatment for non-muscle-invasive bladder cancer (NMIBC). BJU Int 107, 912-918 (2011).

57 Halachmi, S. et al. Intravesical mitomycin C combined with hyperthermia for patients with T1G3 transitional cell carcinoma of the bladder. Urol Oncol 29, 259-264 (2011).

58 Nativ, O. et al. Combined thermo-chemotherapy for recurrent bladder cancer after bacillus Calmette-Guerin. J Urol 182, 1313-1317 (2009).

59 van der Heijden, A. G. et al. Preliminary European results of local microwave hyperthermia and chemotherapy treatment in intermediate or high risk superficial transitional cell carcinoma of the bladder. Eur. Urol. 46, 65-71 (2004).

60 Colombo, R. et al. Multicentric study comparing intravesical chemotherapy alone and with local microwave hyperthermia for prophylaxis of recurrence of superficial transitional cell carcinoma. J. Clin. Oncol. 21, 4270-4276 (2003).

61 Kiss, B., Schneider, S., Thalmann, G. N. \& Roth, B. Is thermochemotherapy with the Synergo system a viable treatment option in patients with recurrent non-muscle-invasive bladder cancer? Int. J. Urol. 22, 158-162 (2015).

62 Volpe, A. et al. Thermochemotherapy for non-muscle-invasive bladder cancer: is there a chance to avoid early cystectomy? Urol Int 89, 311-318 (2012).

63 Moskovitz, B., Halachmi, S., Moskovitz, M. \& Nativ, O. 10-year single-center experience of combined intravesical chemohyperthermia for nonmuscle invasive bladder cancer. Future Oncol. 8, 1041-1049 (2012). 
Alfred Witjes, J., Hendricksen, K., Gofrit, O., Risi, O. \& Nativ, O. Intravesical hyperthermia and mitomycin-C for carcinoma in situ of the urinary bladder: experience of the European Synergo working party. World J Urol 27, 319-324, doi:10.1007/s00345-009-0384-2 (2009).

65 Moskovitz, B. et al. Thermo-chemotherapy for intermediate or high-risk recurrent superficial bladder cancer patients. Ann. Oncol. 16, 585-589 (2005).

66 Gofrit, O. N. et al. Combined local bladder hyperthermia and intravesical chemotherapy for the treatment of high-grade superficial bladder cancer. Urology 63, 466-471 (2004).

67 Kamat, A. M. et al. Definitions, End Points, and Clinical Trial Designs for Non-Muscle-Invasive Bladder Cancer: Recommendations From the International Bladder Cancer Group. J. Clin. Oncol. 34, 1935-1944 (2016).

68 Hounsome, L. S., Verne, J., McGrath, J. S. \& Gillatt, D. A. Trends in operative caseload and mortality rates after radical cystectomy for bladder cancer in England for 1998-2010. Eur. Urol. 67, 1056-1062 (2015).

69 Lammers, R. J. et al. The role of a combined regimen with intravesical chemotherapy and hyperthermia in the management of non-muscle-invasive bladder cancer: a systematic review. Eur. Urol. 60, 81-93 (2011).

70 Rigatti, P., Lev, A. \& Colombo, R. Combined intravesical chemotherapy with mitomycin C and local bladder microwave-induced hyperthermia as a preoperative therapy for superficial bladder tumors. A preliminary clinical study. Eur Urol 20, 204-210 (1991).

71 Rath-Wolfson, L., Moskovitz, B., Dekel, Y., Kugel, V. \& Koren, R. Combined intravesical hyperthermia and mitomycin chemotherapy: a preliminary in vivo study. Int. J. Exp. Pathol. 84, 145-152 (2003).

72 Sousa, A. et al. A clinical trial of neoadjuvant hyperthermic intravesical chemotherapy (HIVEC) for treating intermediate and high-risk non-muscle invasive bladder cancer. Int. J. Hyperthermia 30, 166-170 (2014).

73 Chua, T. C. et al. Intraoperative hyperthermic intraperitoneal chemotherapy after cytoreductive surgery in ovarian cancer peritoneal carcinomatosis: systematic review of current results. J. Cancer Res. Clin. Oncol. 135, 1637-1645, doi:10.1007/s00432-009-0667-4 (2009).

74 Gill, R. S. et al. Treatment of gastric cancer with peritoneal carcinomatosis by cytoreductive surgery and HIPEC: a systematic review of survival, mortality, and morbidity. J. Surg. Oncol. 104, 692-698, doi:10.1002/jso.22017 (2011).

75 Verwaal, V. J. et al. Randomized trial of cytoreduction and hyperthermic intraperitoneal chemotherapy versus systemic chemotherapy and palliative surgery in patients with peritoneal carcinomatosis of colorectal cancer. J. Clin. Oncol. 21, 3737-3743 (2003).

76 Soria, F. et al. Efficacy and safety of a new device for intravesical thermochemotherapy in non-grade 3 BCG recurrent NMIBC: a phase I-II study. World J Urol 34, 189-195 (2016).

77 Milla, P. et al. Intravesical thermo-chemotherapy based on conductive heat: a first pharmacokinetic study with mitomycin $\mathrm{C}$ in superficial transitional cell carcinoma patients. Cancer Chemother Pharmacol 73, 503-509 (2014).

78 Garnick, M. B., Schade, D., Israel, M., Maxwell, B. \& Richie, J. P. Intravesical doxorubicin for prophylaxis in the management of recurrent superficial bladder carcinoma. J Urol 131, 43-46 (1984).

79 Zhao, P. et al. NIR-driven Smart Theranostic Nanomedicine for On-demand Drug Release and Synergistic Antitumour Therapy. Scientific reports 5, 14258, doi:10.1038/srep14258 (2015).

80 Mikhail, A. S. et al. Lyso-thermosensitive liposomal doxorubicin for treatment of bladder cancer. Int. J. Hyperthermia 10, 1-8 (2017).

81 Shan, K., Lincoff, A. M. \& Young, J. B. Anthracycline-induced cardiotoxicity. Ann Intern Med 125, 47-58 (1996).

82 Xing, M., Yan, F., Yu, S. \& Shen, P. Efficacy and Cardiotoxicity of Liposomal DoxorubicinBased Chemotherapy in Advanced Breast Cancer: A Meta-Analysis of Ten Randomized Controlled Trials. PLoS One 10, e0133569, doi:10.1371/journal.pone.0133569 (2015).

83 Ekin, R. G. et al. Intravesical bacillus Calmette-Guerin versus chemohyperthermia for highrisk non-muscle-invasive bladder cancer. Can. Urol. Assoc. J. 9 (2015).

84 EU Clinical Trials Register. (https://www.clinicaltrialsregister.eu/ctrsearch/search?query=eudract number:2013-002628-18 (EudraCT: 2013-002628-18)). International Standard Randomised Controlled Trial Number. (http://www.isrctn.com/ISRCTN23639415 (ISRCTN23639415)).

86 Tan, W. S., Palou, J. \& Kelly, J. MP15-18 SAFETY AND TOLERABILITY ANALYSIS OF HYPERTHERMIC INTRAVESICAL MITOMYCIN TO MITOMYCIN ALONE IN HIVEC I AND HIVEC II: AN ANALYSIS OF 307 PATIENTS. The Journal of Urology 197, e177 (2017).

87 Di Stasi, S. M. et al. Electromotive versus passive diffusion of mitomycin C into human bladder wall: concentration-depth profiles studies. Cancer Res 59, 4912-4918 (1999). 
Stasi, S. M. D. et al. Electromotive Delivery of Mitomycin C into Human Bladder Wall. Cancer Res. 57, 875-880 (1997).

89 Di Stasi, S. M. et al. Electromotive versus passive diffusion of mitomycin C into human bladder wall: concentration-depth profiles studies. Cancer Res. 59, 4912-4918 (1999). Di Stasi, S. M. et al. Electromotive instillation of mitomycin immediately before transurethral resection for patients with primary urothelial non-muscle invasive bladder cancer: a randomised controlled trial. The lancet oncology 12, 871-879, doi:10.1016/s14702045(11)70190-5.

91 Brausi, M. et al. Intravesical electromotive administration of drugs for treatment of superficial bladder cancer: a comparative Phase II study. Urology 51, 506-509 (1998).

92 Gan, C. et al. Sequential bacillus Calmette-Guerin/Electromotive Drug Administration of Mitomycin $\mathrm{C}$ as the Standard Intravesical Regimen in High Risk Nonmuscle Invasive Bladder Cancer: 2-Year Outcomes. J Urol 195, 1697-1703 (2016).

93 Di Stasi, S. M. et al. Sequential BCG and electromotive mitomycin versus BCG alone for highrisk superficial bladder cancer: a randomised controlled trial. The Lancet. Oncology 7, 43-51 (2006).

94 Di Stasi, S. M. et al. Intravesical electromotive mitomycin C versus passive transport mitomycin $\mathrm{C}$ for high risk superficial bladder cancer: a prospective randomized study. J Urol 170, 777-782 (2003).

95 Riedl, C. R., Knoll, M., Plas, E. \& Pfluger, H. Intravesical electromotive drug administration technique: preliminary results and side effects. J Urol 159, 1851-1856 (1998).

96 Jung, J. H. et al. Intravesical electromotive drug administration for non-muscle invasive bladder cancer. The Cochrane database of systematic reviews 9, Cd011864, doi:10.1002/14651858.CD011864.pub2 (2017).

97 Bachir, B. G. et al. Contemporary cost-effectiveness analysis comparing sequential bacillus Calmette-Guerin and electromotive mitomycin versus bacillus Calmette-Guerin alone for patients with high-risk non-muscle-invasive bladder cancer. Cancer 120, 2424-2431 (2014). 98 National Institute for Clinical Excellence. Guide to the methods of technology appraisal. (2013).

99 Grosse, S. D. Assessing cost-effectiveness in healthcare: history of the $\$ 50,000$ per QALY threshold. Expert review of pharmacoeconomics \& outcomes research 8, 165-178, doi:10.1586/14737167.8.2.165 (2008).

100 ClinicalTrials.gov. (https://clinicaltrials.gov/ct2/show/NCT02722538 (NCT02722538)).

101 Friedman, B. et al. PD11-05 THE CHEMOABLATIVE EFFECT OF VESIGEL INSTILLATION IN PATIENTS WITH NMIBC - PRELIMINARY RESULTS. The Journal of urology 195, e289-e290, doi:http://dx.doi.org/10.1016/i.juro.2016.02.845 (2016). 